\title{
Costa Rica: Staff Report for the 2009 Article IV Consultation and First Review Under the Stand-By Arrangement; Press Release and Public Information Notice on the Executive Board Discussion; and Statement by the Executive Director for Costa Rica
}

In the context of the 2009 Article IV Consultation and First Review Under the Stand-By Arrangement, the following documents have been released and are included in this package:

- The staff report for the 2009 Article IV Consultation and First Review Under the Stand-By Arrangement prepared by a staff team of the IMF, following discussions that ended on August 20, 2009, with the officials of Costa Rica on economic developments and policies. Based on information available at the time of these discussions, the staff report was completed on September 9, 2009. The views expressed in the staff report are those of the staff team and do not necessarily reflect the views of the Executive Board of the IMF.

- A press release and a Public Information Notice (PIN) summarizing the views of the Executive Board as expressed during its September 23, 2009 discussion of the staff report that approved the First Review Under the Stand-By Arrangement and concluded the 2009 Article IV Consultation.

- $\quad$ A statement by the Executive Director for Costa Rica.

The documents listed below have been separately released (they are also included in the staff report).

Letter of Intent sent to the IMF by the authorities of Costa Rica*

Memorandum of Economic and Financial Policies by the authorities of Costa Rica* Technical Memorandum of Understanding*

The policy of publication of staff reports and other documents allows for the deletion of marketsensitive information.

\author{
Copies of this report are available to the public from \\ International Monetary Fund • Publication Services \\ $70019^{\text {th }}$ Street, N.W. • Washington, D.C. 20431 \\ Telephone: (202) 623-7430 • Telefax: (202) 623-7201 \\ E-mail: publications@imf.org•Internet: http://www.imf.org
}

Price: $\$ 18.00$ a copy

\section{International Monetary Fund Washington, D.C.}


INTERNATIONAL MONETARY FUND

COSTA RICA

\title{
Staff Report for the 2009 Article IV Consultation, First Review Under the Stand-By Arrangement, and Request for Modification of Performance Criteria
}

\author{
Prepared by the Western Hemisphere Department \\ (In consultation with other departments)
}

Approved by Miguel A. Savastano (WHD) and Dominique Desruelle (SPR)

September 9, 2009

\section{EXECUTIVE SUMMARY}

- Costa Rica's economy has been hit hard by the global crisis, but active policies have helped preserve stability and mitigate the negative impact on growth. Economic activity is expected to recover slowly, in line with the expected turnaround in trading partner countries. For 2009, staff projects a real GDP decline of 1.5 percent, followed by positive growth above 2 percent in 2010 . Inflation is projected to decline to 5 percent at end-2009, the lowest level in more than three decades.

- Performance under the IMF-supported program has been strong, with the authorities meeting all end-June performance criteria and structural benchmarks. The 15-month Stand-By Arrangement is expected to remain precautionary and will continue to support confidence through the provision of a liquidity buffer. The program has been revised to partly accommodate lower-thanexpected fiscal revenues through higher deficits in 2009-10. This will help protect social spending and support domestic demand, while keeping the domestic borrowing requirement and the debt-toGDP ratio within reasonable margins.

- The medium-term outlook for Costa Rica's economy remains generally favorable.

Consolidating domestic and external stability and sustaining high growth rates will require, however, actions on a number of fronts.

$>$ After a very large fiscal expansion, which is supporting demand amidst the global downturn, the authorities will need to reduce the fiscal deficit to keep the debt burden in check and avoid crowding out the private sector.

$>$ Continuous progress in implementing inflation targeting and achieving greater exchange rate flexibility would also be advisable to lock-in the current historically low inflation rate.

$>$ As of mid-2009, the level of the real exchange rate is considered to be broadly in line with its equilibrium level. However, some further accumulation of international reserves seems advisable to further increase the economy's resilience to external shocks.

$>$ The authorities should address remaining shortcomings in the supervision, prudential framework, and safety net for banks.

- Costa Rica has accepted the obligations of Article VIII, Sections 2, 3, and 4, and its exchange system remains free of restrictions on the making of payments and transfers for current transactions. The country maintains a crawling exchange rate band regime since October 2006. 


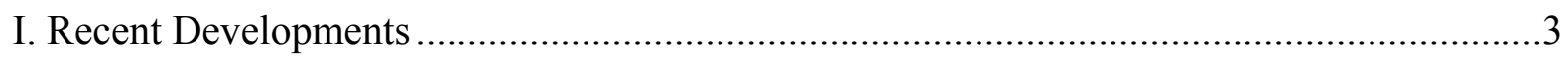

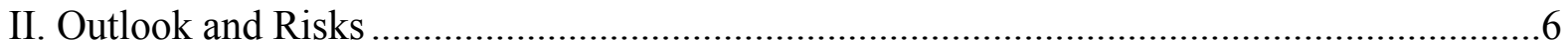

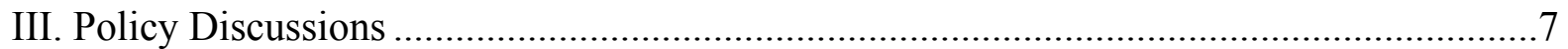

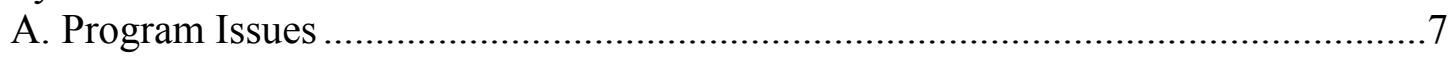

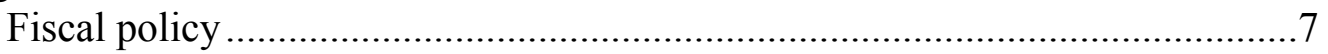

Monetary, exchange rate, and financial sector policies ..............................8

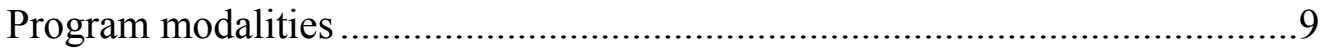

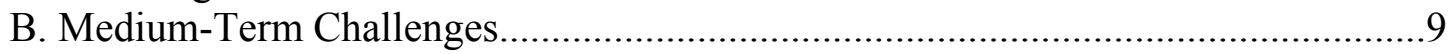

Resuming fiscal consolidation .......................................................... 10

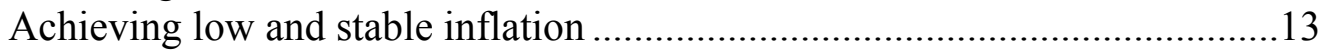

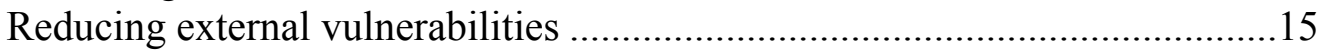

Strengthening the financial sector......................................................16

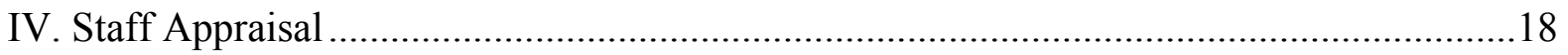

Tables

1. Selected Economic Indicators .....................................................................................20

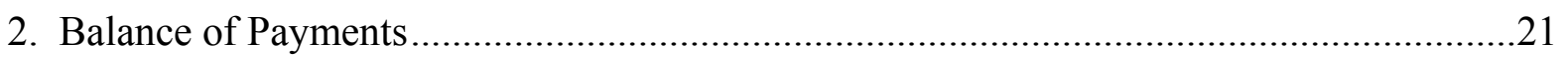

3. Central Government Balance (in percent of GDP) ........................................................22

4. Central Government Balance (in billions of colones)...................................................23

5. Combined Public Sector Operations (in percent of GDP) ..........................................24

6. Combined Public Sector Operations (in billions of colones) ........................................25

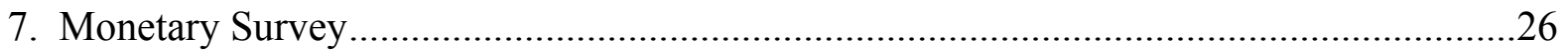

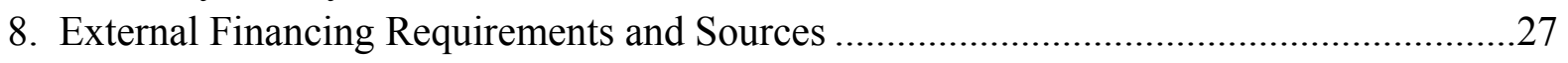

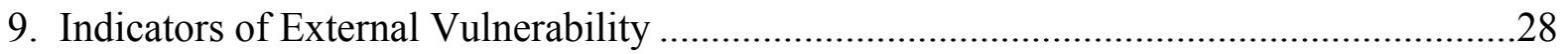

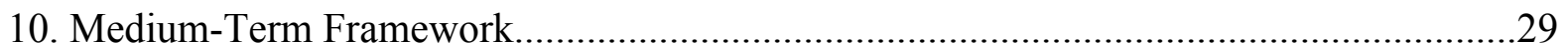

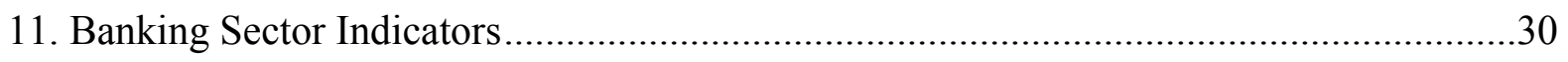

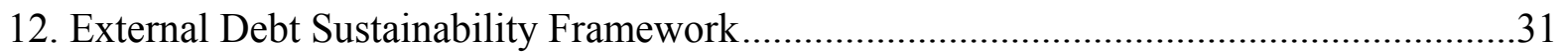

13. Combined Public Sector Debt Sustainability Framework ............................................32

Figures

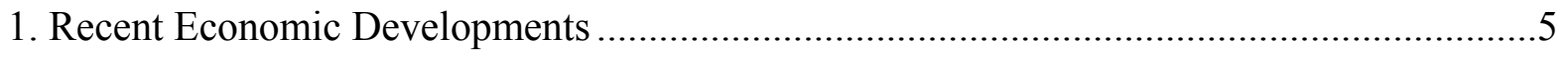

2. General Government Expenditure and Revenue Comparison ........................................12

Boxes

1. Previous Article IV Recommendation ......................................................................... 10

2. Assessment of Costa Rica's Real Exchange Rate........................................................15

Attachments

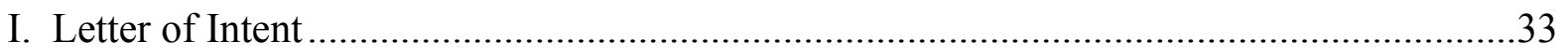

II. Supplement to the Memorandum of Economic and Financial Policies ............................35

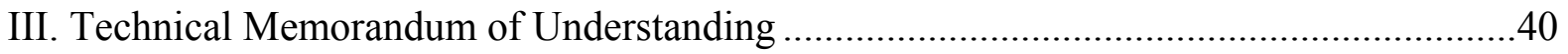




\section{RECENT DEVELOPMENTS}

1. The 2009 Article IV Consultation and First Review under the Stand-By Arrangement ( $S B A$ ) took place against the background of a global crisis that has had considerable effects on Costa Rica. ${ }^{l}$ Economic activity during the first half of 2009 was severely affected by the global downturn, but domestic and external stability were generally preserved (Figure 1).

- Output growth was substantially weaker than anticipated. Real GDP contracted by 4.8 percent $(\mathrm{y} / \mathrm{y})$ during the first quarter, driven by a sharp fall in inventories and a decline in sectors most dependent on external conditions. Although, the index of economic activity declined on a year-over-year basis in the second quarter, it rose 1.2 percent on a quarter-on-quarter basis, suggesting that the decline in output may be reaching an end. Inflation has remained on a firm downward path, falling from 13.9 percent in December 2008 to 5.7 percent in August 2009.

- The fiscal deficit of the central government (without adjustment for TUDES) reached 1.2 percent of GDP in the first half of 2009. ${ }^{2}$ This smaller-than-projected outturn reflected cautious expenditure execution, which more than offset a revenue shortfall of 6 percent ( $\mathrm{C} 73$ billion) compared to program projections. Fiscal policy nonetheless provided strong support to domestic demand, as noninterest expenditures rose 14 percent $(\mathrm{y} / \mathrm{y})$ in real terms. The central government's gross financing requirements, which included large amortization payments, were met through domestic bond issuances.

- $\quad$ The balance of payments did not experience major pressures. During the first half of 2009, the external current account deficit narrowed sharply to 0.2 percent of GDP (compared to a deficit of 2.6 percent of GDP envisaged in the program), as imports contracted much more than expected. Net capital inflows also declined, reflecting lower foreign direct investment and the repayment of credit lines by domestic banks and corporations, but there were no confidence-related outflows and the overall balance of payments recorded a small surplus of US $\$ 137$ million. The exchange rate remained close to the ceiling (i.e., most depreciated end) of the currency band throughout the period, though occasionally traded up to 2 percent below the ceiling. Central bank (BCCR) interventions were generally moderate. In light of the strength of the balance of payments position, the authorities did not make the first purchase (about $\$ 500$ million) of the SBA.

\footnotetext{
${ }^{1}$ Discussions were held in San José during August 10-20, 2009. The staff team comprised by A. Bauer (Head), R. Luzio, M. Nozaki (all WHD), and A. Thomas (SPR) was joined by J. Gramajo (OED) and F. Delgado (Regional Resident Representative) in some of the discussions. They met with Central Bank Governor Gutiérrez, Finance Minister Phillips, other senior officials, and representatives of the financial sector and academia.

${ }^{2}$ TUDES are inflation-indexed bonds. The inflation adjustment of these bonds is recorded as interest expenditure and thus affects the deficit calculated by staff.
} 
- $\quad$ Domestic financial markets were also broadly stable. Real interest rates of bank deposits and government bonds increased, as nominal rates did not fall by as much as inflation. In the banking system, the nonperforming loan ratio rose moderately and profitability declined. However, liquidity and solvency indicators remained generally adequate and banks reduced their net foreign exposure by repaying external credit lines. In June 2009, the authorities canceled the US\$500 million financial sector credit line from the IADB, as banks showed little interest to tap this (fairly expensive) funding source.

2. Performance against program targets was strong. The authorities met all quantitative performance criteria for end-June, most of them with considerable margins (see text table below). They also implemented well ahead of the target date the benchmarks referring to daily forecasting of systemic liquidity and monthly monitoring reports on the soundness of the banking sector. The structural benchmark on the planned unification of money markets was initially delayed due to operational difficulties. However, a new platform that allows the integration of the currently segmented money markets became operational in early August.

Costa Rica: Quantitative Performance Measures 1/

\begin{tabular}{|c|c|c|c|c|}
\hline & \multicolumn{4}{|c|}{2009 Program } \\
\hline & \multicolumn{2}{|c|}{ End-March 2/ } & \multicolumn{2}{|c|}{ End-June } \\
\hline & $\overline{E B S / 09 / 41}$ & Actual & EBS/09/41 & Actual \\
\hline \multicolumn{5}{|l|}{ Quantitative Performance Criteria } \\
\hline Floor on cash balance of the Central Government (cumulative) & -210 & -106 & -312 & -206 \\
\hline Ceiling on the debt stock of the Central Government & 4,303 & 4,239 & 4,356 & 4,338 \\
\hline Ceiling on NDA of the Central Bank & -915 & $-1,301$ & -786 & $-1,244$ \\
\hline Floor on NIR of the Central Bank (million of US\$) & 3,500 & 4,167 & 3,350 & 3,936 \\
\hline \multicolumn{5}{|l|}{ Continuous Performance Criteria } \\
\hline Accumulation of external debt arrears & 0 & 0 & 0 & 0 \\
\hline \multicolumn{5}{|l|}{ Indicative targets } \\
\hline Floor on cash balance of the combined public sector (cumulative) & -146 & -43 & -325 & -179 \\
\hline \multicolumn{5}{|l|}{ Memorandum item } \\
\hline Base money & 1,102 & 1,101 & 1,144 & 1,024 \\
\hline
\end{tabular}

Sources: Central Bank of Costa Rica; Ministry of Finance; and Fund staff projections.

$1 /$ In billion of colones, unless otherwise indicated.

$2 /$ Indicative target. Performance criteria were only set from end-June onward. 


\section{Figure 1. Recent Economic Developments}

Economic growth in 2009 has been substantially weaker than anticipated, but there is some evidence that the real GDP decline may be reaching an end. Inflation remains on a firm downward path.
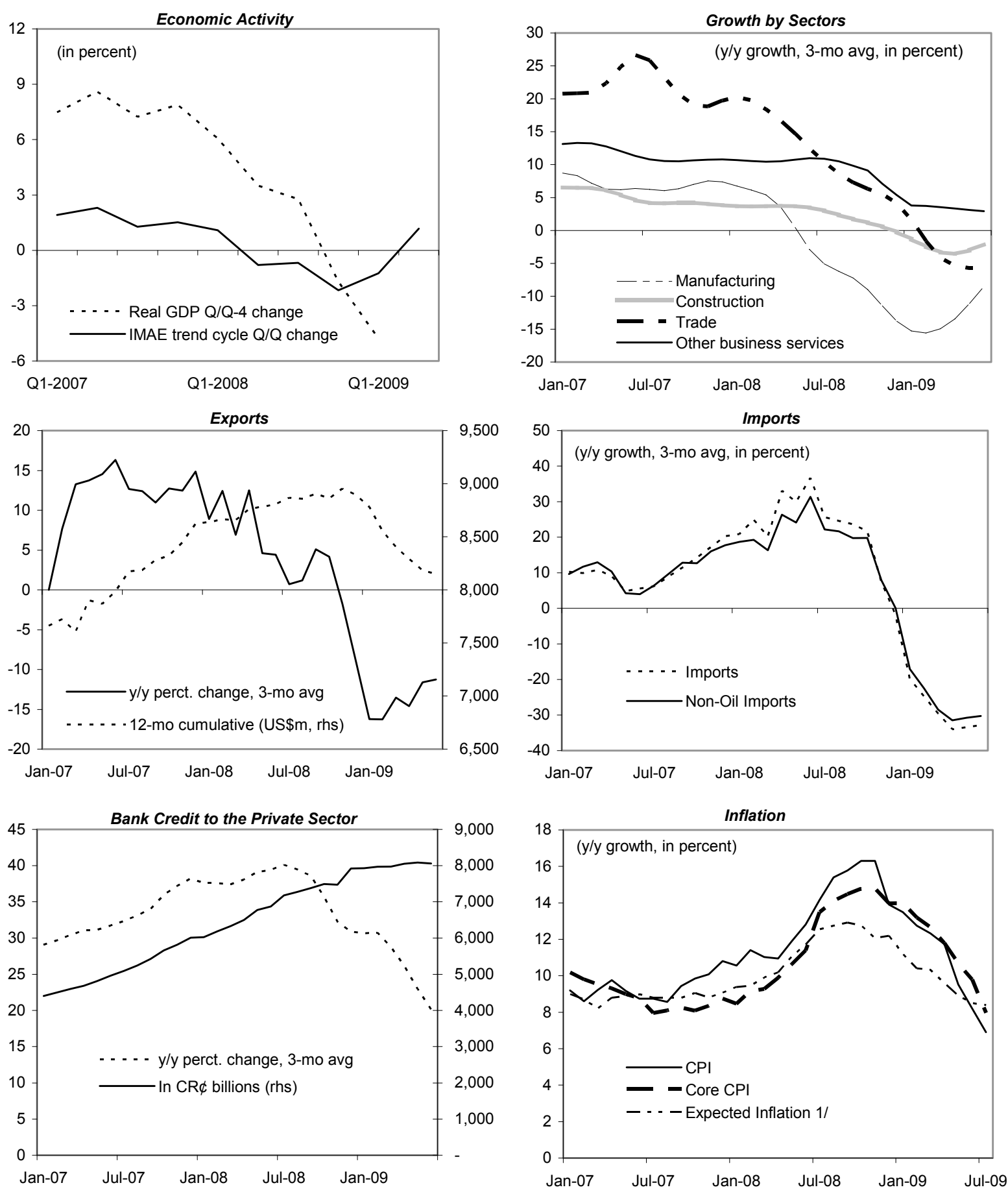

Sources: Country authorities; and Fund staff calculations. 1/ Monthly survey of the Central Bank of Costa Rica. 


\section{OUTLOOK AND RISKS}

3. The outlook for Costa Rica's economy is of a gradual recovery, driven by the projected turnaround in trading partner countries. The authorities' economic program will remain focused on strengthening the external position, easing the adjustment to the global downturn, and supporting the nascent recovery.

- The macroeconomic framework of the program has been revised to reflect the outturns of the first half of 2009 and changes in the global economic outlook (Table 1). Real GDP in 2009 is now expected to decline by 1.5 percent (compared to the 0.5 percent growth envisaged at program approval). This projection takes into account recent signs of a turnaround in output and more favorable prospects for technology and corporate services exports. Real GDP growth for 2010 has been revised upward to 2.3 percent, reflecting mainly the improved outlook for the U.S. economy. Inflation is now projected to decline to 5 percent at end-2009 and remain unchanged in 2010 (compared to projected inflation rates of 8 percent and 7 percent, respectively, in the original program). The external current account deficit for 2009 is expected to decline to 3.6 percent of GDP (down from 5.3 percent of GDP at program approval), and thereafter increase to 4.8 percent of GDP in 2010, as oil prices rise and non-oil import growth bounces back. The balance of payments is projected to remain in overall balance in 2009 (excluding the inflow from the SDR allocations), as lower FDI, the net repayment of external credit lines, and lower disbursements of official loans are expected to lower the capital account surplus by broadly the same amount as the projected decline in the current account deficit. For 2010, the balance of payments is expected to record a small surplus.

- $\quad$ Over the medium term, staff projects GDP to grow at about 4.5 percent. The economy's output gap is expected to narrow as output growth accelerates to over 5 percent by 2014, somewhat above the estimated potential rate of 4.2 percent. Inflation is projected to fall from 5 percent to around 4 percent, broadly consistent with average trading partner inflation. The external current account deficit is expected to hover around 5 percent of GDP and to be fully financed by FDI inflows so that external debt declines modestly to about 27 percent of GDP. Key for this mediumterm scenario is a significant fiscal consolidation that raises public savings (see paragraphs 13-17) and the maintenance of prudent credit policies.

4. Risks. Immediate risks to the program have moderated, but remain somewhat tilted to the downside. The external current account has adjusted more quickly than anticipated, external short-term debt has declined, and reserves have increased. The stabilization of global and domestic financial conditions has also reduced the risk of a sudden loss in confidence that could trigger destabilizing capital outflows. However, confidence could weaken again, and the colón could come under pressure, if the incipient recovery falters, the situation of banks deteriorates too fast, or the fiscal deficit gets out of control. A fiscal deficit much higher than the revised program target for 2010, in particular, would also put pressure on domestic interest rates, affect debt dynamics and expectations, and could jeopardize macroeconomic 
stability. The main risk to the growth outlook over the medium term is slow implementation of structural reforms, including approval of key laws to increase the tax revenue intake, strengthen the monetary policy framework, and address some remaining shortcomings in financial sector supervision and regulation. Although general elections will be held in early February 2010, the risk of instability ahead of the elections is very low.

\section{Policy Discussions}

\section{A. Program Issues}

5. Program discussions focused on revising the fiscal targets in light of a much lower revenue forecast. The authorities restated their interest in keeping the SBA focused on supporting confidence through the provision of a large liquidity buffer and in maintaining the arrangement precautionary.

\section{Fiscal policy}

6. The authorities and staff agreed on a revised fiscal program for 2009-10 that seeks to strike a balance between providing continued support to domestic demand and avoiding an excessive increase in domestic borrowing and public debt.

- For 2009, central government revenues are expected to fall short by $\mathrm{C} 290$ billion (1.7 percent of GDP) from the original program projection. The revenue shortfall is largely a result of lower growth and a sharper-than-expected decline in import-related taxes. About half of the lower revenue will be accommodated through a higher deficit to protect the planned increase in government noninterest spending (which is projected to rise by 20 percent in real terms), including the targeted transfer program $A V A N C E M O S$ and noncontributory pensions. ${ }^{3}$ Overall, the revised program now envisages a central government deficit of 4.1 percent of GDP and a deficit of the combined public sector of 4.8 percent of GDP (compared to 3.2 and 4.1 percent of GDP, respectively, in the original program). The additional deficit will be financed through higher domestic borrowing and, if necessary, a drawdown of central government deposits (which amounted to 1.2 percent of GDP as of end-August). ${ }^{4}$

- For 2010, the program foresees a deficit for the central government of 4.1 percent of GDP and a combined public sector deficit of 4.7 percent of GDP. Although these deficits are higher than those envisaged in the original program (3.2 percent and 4.1 percent of GDP, respectively), they continue to imply a small adjustment in structural terms. The authorities expect a cyclical recovery of revenues and are taking additional measures to increase revenues by 0.4 percent of GDP (i.e., through a new

\footnotetext{
${ }^{3}$ The government's noncontributory pension program is focused on providing monetary transfers to the elderly poor who are not covered by Costa Rica's contributory pension systems.

${ }^{4}$ Demand for treasury bonds will be supported by a temporary increase in the ceiling for pension fund investments in public sector instruments (from 65 to 70 percent of their portfolio).
} 
property tax and a yet-to-be-approved tax on casinos and the virtual gambling industry). Staff expressed concern about the continued strong growth of current spending envisaged for 2010, and noted the risks that this may pose for macroeconomic stability and the external position. The authorities recognized that the envisaged fiscal expansion was large, but noted that the planned spending was central to their objective to foster investment in human and physical capital, and felt that the risks to stability were manageable. In this regard, to reduce the risk of crowding out the private sector, the authorities noted that they plan to increase their reliance on foreign borrowing, including by using the US $\$ 500$ million contingent credit line from the World Bank (currently awaiting approval in the Legislative Assembly). Overall, the revised fiscal deficits and macroeconomic framework are expected to increase the debt of the combined public sector to 41.6 percent of GDP in 2010, 3 percentage points more than envisaged in the original program.

\section{Monetary, exchange rate, and financial sector policies}

7. Monetary policy will maintain a cautious easing bias. Staff agreed that the BCCR had a strong basis for lowering its policy rate by 100 bps to 9 percent in mid-July, given the sharp deceleration in inflation. However, staff and the authorities agreed that the room for further gradual cuts would depend critically on clear evidence of a further decline in inflation and depreciation expectations (both presently at about 8 percent on a 12-month horizon), to ensure the attainment of the inflation target, and reduce risks of pressures on the colón.

\section{The program's NIR targets will be adjusted upwards by the amount of the}

SDR allocation. While the authorities and staff agreed that the current level of reserves provided ample room to absorb temporary exchange rate pressures, they also agreed that Costa Rica would benefit from higher reserves coverage (see paragraph 23). Allocating their share of the special and general SDR allocation (about US\$205 million) to gross reserves was therefore seen as a good opportunity to strengthen NIR. The program NDA targets were correspondingly revised downward.

9. While the banking system has fared relatively well, the authorities have to remain vigilant and implement envisaged measures to strengthen the financial sector safety net. Although concerns about risks to bank liquidity have eased, the superintendency of banks (SUGEF) will continue to closely monitor developments in the banking sector, particularly credit risks. The authorities are working on draft laws to strengthen the bank resolution framework and create a limited deposit guarantee scheme (both structural benchmarks under the program). In view of the complementarities between the two laws, it was agreed that it would be preferable to submit them to the Legislative Assembly at the same time (i.e., by endDecember 2009). 


\section{Program modalities}

10. Current modalities for program monitoring will remain in place. In light of continued uncertainty about the external environment and fiscal revenues, the authorities and staff agreed to maintain quarterly program reviews for the time being. The program now includes quantitative performance criteria through end-December 2009. Quantitative performance criteria for end-March 2010 (the last test date under the arrangement) will be set during the second review mission in early November. Structural benchmarks remain unchanged, except for the above noted modification of the target date for the submission of a draft law to strengthen the bank resolution process.

11. Safeguards assessment. The safeguards assessment of the BCCR finalized in July 2009 found that the bank has a generally sound operating control environment. To further strengthen the BCCR's safeguards framework, the assessment recommended the appointment of an external auditor to conduct annual audits of the financial statements from 2008 onwards, the implementation of International Financial Reporting Standards (IFRS) by 2011, and the establishment of Audit Committee functions. The authorities committed to implement the assessment's recommendations; in particular the BCCR has initiated the process to select an external auditor and will include in the services to be contracted an analysis of the existing gaps between the BCCR's accounting practices and IFRS, in order to establish an action plan for the implementation of IFRS.

\section{B. Medium-Term Challenges}

\section{Costa Rica faces several policy challenges as it recovers from the crisis and seeks to}

achieve high and sustainable growth. While countercyclical fiscal stimulus has been used to mitigate the impact of the global crisis, the government will eventually have to rein in public spending and resume fiscal consolidation to keep public debt manageable and moderate domestic demand growth. At the same time, the rapid decline of inflation provides an ideal opportunity to advance in the transition to an inflation targeting regime and anchor inflation at a low level. The crisis has also underscored the need to continue reducing external vulnerabilities. To this end, greater exchange flexibility and a gradual build-up of international reserve would help increase the economy's resilience to external shocks and continue to support investor confidence. 


\section{Box 1. Previous Article IV Recommendations}

The previous Article IV consultation (February 2008) emphasized the need to lower inflation and complete a reform agenda that included fully implementing the CAFTA-DR trade agreement, making decisive progress toward the transition to inflation targeting, undertaking tax reform, and strengthening financial regulation and supervision.

The global food and oil price shock in 2008 derailed the disinflation strategy. Inflation rose to 16.3 percent in November 2008, before falling to single digit levels in 2009. Partly due to this, progress in the transition to inflation targeting and greater exchange rate flexibility was slow. In January 2009, the authorities increased the rate of crawl of the upper (most depreciated) end of the currency band to 9 percent. They also issued regulations for currency hedging instruments and made progress toward the unification of the segmented money markets. Other recommendations, such as a switch of the policy rate or the replacement of the central bank deposit facility with reverse repos remain outstanding.

The authorities were able to obtain approval of all CAFTA-DR implementation laws by December 2008 . However, the long time it took to approve those laws caused delays for other key legislation such as the VAT reform bill, the consolidated financial supervision bill, and the bill to recapitalize the central bank. Some other recommendations of the previous Article IV consultation, such as the strengthening of the bank resolution framework, are currently being pursued under the SBA.

\section{Resuming fiscal consolidation}

\section{Fiscal policy has helped support domestic demand during the downturn, but the} fiscal position has deteriorated considerably as a result. The cumulative fiscal impulse during 2008-10 is likely to be in order of 3.5 percentage points of GDP, mostly explained by a strong expansion of current primary spending. As a result, the combined public sector debt is now projected to exceed 41 percent of GDP by end-2010, up from a low of 35.8 percent of GDP in 2008. An illustrative passive scenario discussed with the authorities shows that the expected cyclical recovery of revenues together with spending levels broadly similar to those now envisaged for 2009-10 would not be sufficient to place the debt-to-GDP ratio on a downward path until 2014, and would thus keep fiscal vulnerability rather high.

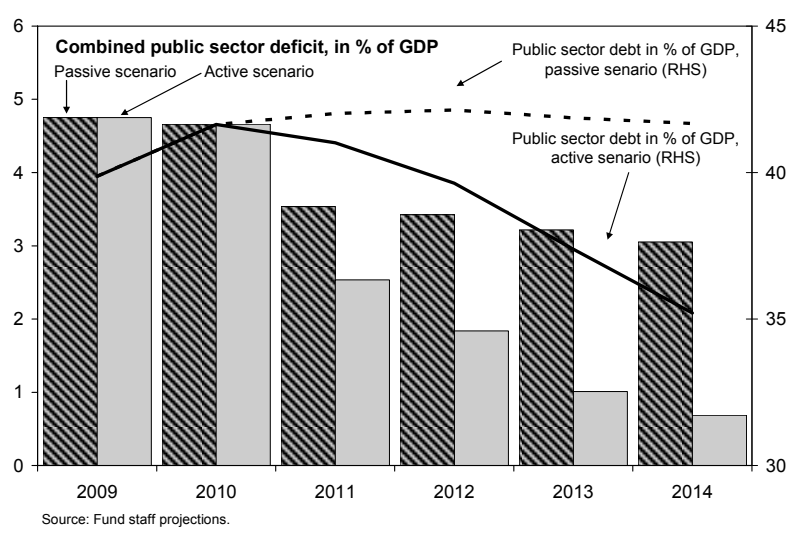

\section{Staff argued that fiscal consolidation should begin as soon as the economic recovery}

takes hold. The consolidation could usefully aim at lowering the debt-to-GDP ratio of the combined public sector to the pre-crisis level of about 35 percent of GDP by 2014. This level of debt, which is also in line with the average public debt-to-GDP ratio of investment grade countries in the $\mathrm{BBB} / \mathrm{A}$ range before the current downturn, would help rebuild room for an effective fiscal response in case of future contingencies. Staff estimates that lowering the public debt ratio to about 35 percent by 2014 would require policy measures of at least 2 percentage points of GDP (to be implemented in 2011-13), in order to reduce the combined 
public sector deficit to less than 1 percent of GDP at the end of the projection period (see text table below).

Costa Rica: Medium-term fiscal scenarios, 2009-2014

\begin{tabular}{|c|c|c|c|c|c|c|c|c|c|c|c|c|}
\hline & \multicolumn{6}{|c|}{ Passive scenario } & \multicolumn{6}{|c|}{ Active scenario } \\
\hline & 2009 & 2010 & 2011 & 2012 & 2013 & 2014 & 2009 & 2010 & 2011 & 2012 & 2013 & 2014 \\
\hline & \multicolumn{12}{|c|}{ (In percent of GDP) } \\
\hline \multicolumn{13}{|l|}{ Central government } \\
\hline Revenue & 14.5 & 15.2 & 15.3 & 15.4 & 15.5 & 15.6 & 14.5 & 15.2 & 16.3 & 16.9 & 17.5 & 17.6 \\
\hline Expenditure & 18.6 & 19.4 & 19.3 & 19.4 & 19.4 & 19.3 & 18.6 & 19.4 & 19.3 & 19.3 & 19.2 & 18.9 \\
\hline Current non-interest & 13.9 & 14.4 & 14.3 & 14.2 & 14.1 & 14.0 & 13.9 & 14.4 & 14.3 & 14.2 & 14.1 & 14.0 \\
\hline Interest & 2.6 & 2.9 & 2.8 & 2.8 & 2.9 & 2.9 & 2.6 & 2.9 & 2.8 & 2.8 & 2.7 & 2.5 \\
\hline Capital & 2.1 & 2.1 & 2.2 & 2.3 & 2.4 & 2.5 & 2.1 & 2.1 & 2.2 & 2.3 & 2.4 & 2.5 \\
\hline Primary balance & -1.5 & -1.2 & -1.2 & -1.2 & -1.0 & -0.9 & -1.5 & -1.2 & -0.2 & 0.3 & 1.0 & 1.1 \\
\hline Overall balance & -4.1 & -4.1 & -4.0 & -4.0 & -3.9 & -3.8 & -4.1 & -4.1 & -3.0 & -2.4 & -1.7 & -1.4 \\
\hline \multicolumn{13}{|c|}{ Combined public sector (CPS) } \\
\hline Overall balance & -4.8 & -4.7 & -3.5 & -3.4 & -3.2 & -3.1 & -4.8 & -4.7 & -2.5 & -1.8 & -1.0 & -0.7 \\
\hline Central government debt & 28.9 & 31.0 & 32.7 & 34.2 & 35.3 & 36.3 & 28.9 & 31.0 & 31.7 & 31.6 & 30.7 & 29.8 \\
\hline CPS debt & 39.9 & 41.6 & 42.0 & 42.1 & 41.9 & 41.7 & 39.9 & 41.6 & 41.0 & 39.6 & 37.4 & 35.2 \\
\hline \multicolumn{13}{|l|}{ Memorandum items: } \\
\hline Nominal GDP growth (\%) & 7.3 & 7.6 & 8.6 & 9.4 & 10.2 & 10.1 & 7.3 & 7.6 & 8.6 & 9.4 & 10.2 & 10.1 \\
\hline Real GDP growth (\%) & -1.5 & 2.3 & 3.5 & 4.5 & 5.2 & 5.2 & -1.5 & 2.3 & 3.5 & 4.5 & 5.2 & 5.2 \\
\hline
\end{tabular}

Source: Fund staff projections.

15. The authorities agreed on the need to achieve a significant fiscal consolidation over the medium term. They noted that the prudent policies of previous years had provided the scope for rapid implementation of countercyclical spending when the global crisis hit, and recognized the need to adjust fiscal policies to bring the debt dynamics on a downward path and regain fiscal space. However, the authorities were of the view that there was scope for a somewhat less ambitious pace of fiscal consolidation and a higher debt-to-GDP ratio objective since the public debt burden would remain well below historical levels for Costa Rica.

\section{There was broad agreement that the authorities' spending priorities and some} institutional features limit the scope for making the fiscal consolidation hinge on expenditure restraint. A recent World Bank/IDB public expenditure review has highlighted spending needs on transport infrastructure and secondary education. In addition, the authorities felt strongly that the expansion of the social safety net had helped contain the social fallout from the crisis, and was critical to poverty alleviation. The political scope for reducing rigidities (i.e., earmarking) is also limited, and the importance of health, education, and security sectors on the wage bill leave limited room to increase nonwage spending in the near term. Although, staff agreed that the level of government spending was not out of line with comparators (Figure 2), it noted that its composition was far from ideal as it did not leave room for much needed increases in public investment. Staff also stressed the importance of continued efforts to increase the efficiency of public spending, and welcomed the authorities' initiatives to strengthen the budget formulation process and put in place a medium-term expenditure framework. 
Figure 2. General Government Expenditure and Revenue Comparison

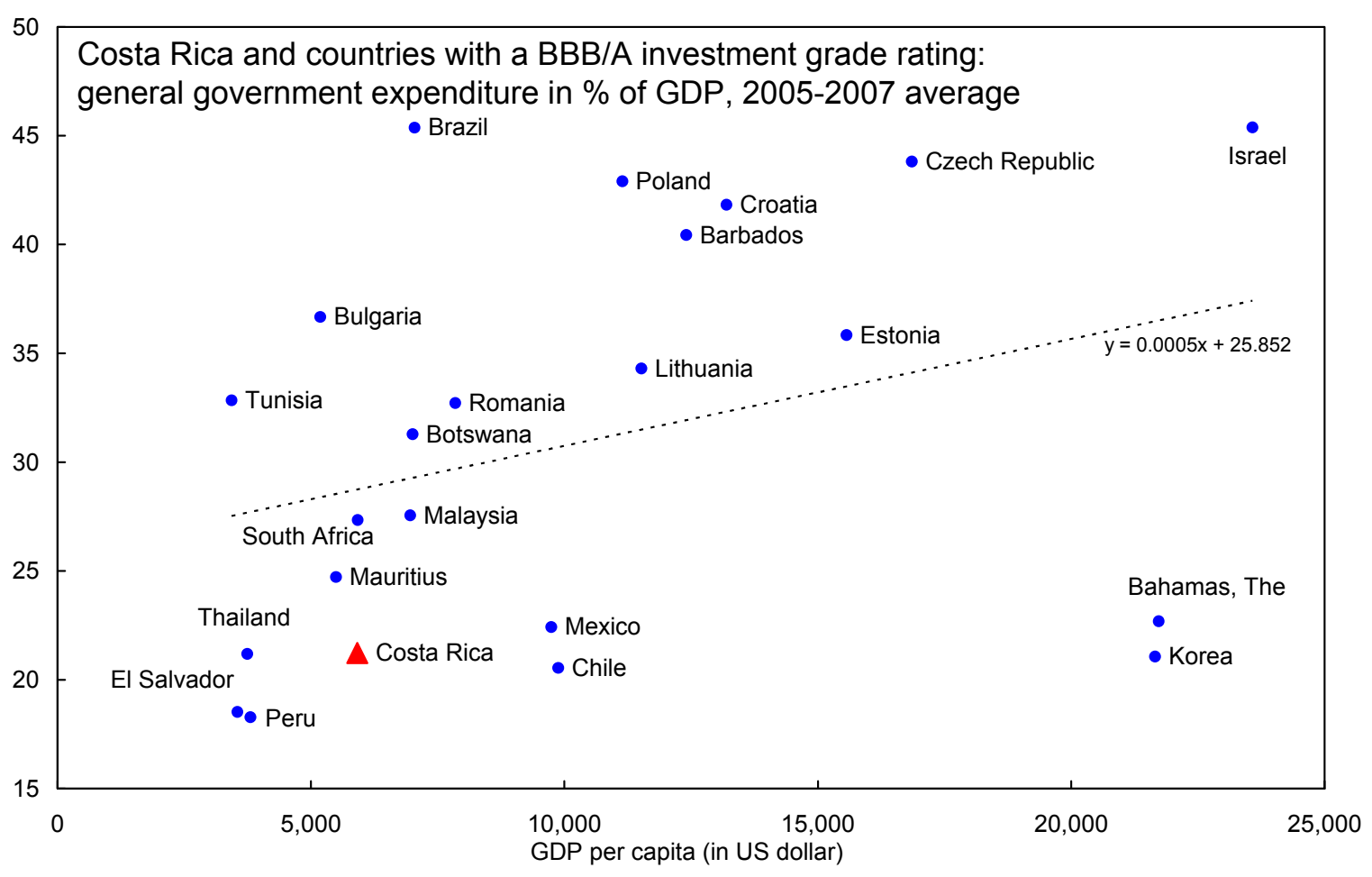

Source: World Economic Outlook database.

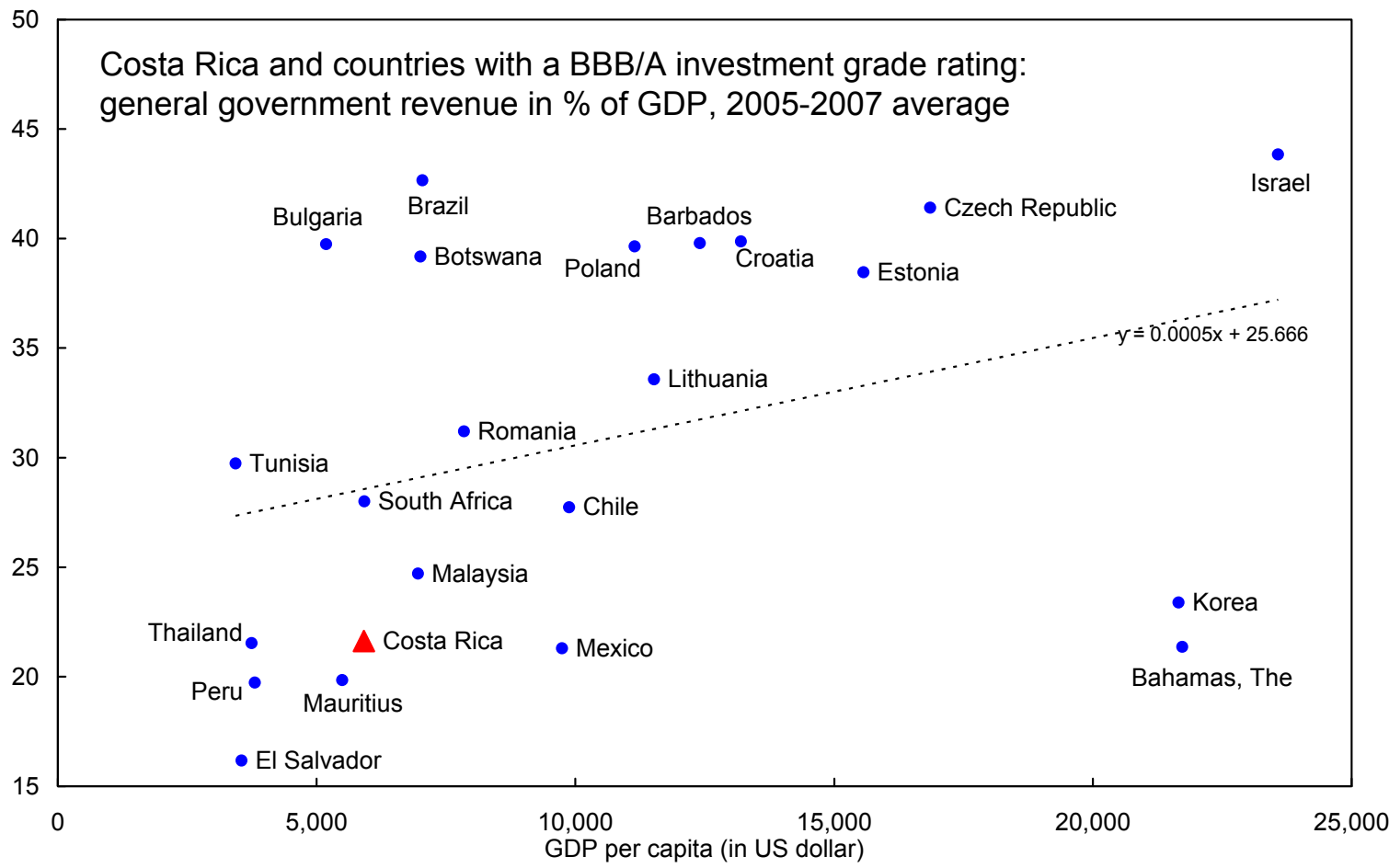

Source: World Economic Outlook database. 
17. Fiscal consolidation will ultimately hinge on increasing tax revenues. Staff argued that many of the recommendations of the 2006 FAD tax policy review remained valid, and that a combination of a broadening of the tax base, further improvements in tax administration, and selective tax rate increases could yield about 2 percentage points of GDP in the next few years. ${ }^{5}$ The authorities felt that an increase of the suggested magnitude could be feasible. They pointed to their ongoing efforts to strengthen tax administration and indicated their preference to increase the revenue intake through the expansion of the income and sales tax bases (including streamlining of exemptions and the incorporation of currently untaxed incomes) rather than raising tax rates. ${ }^{6}$ These proposals are reflected in two draft tax reform bills, one of which (i.e., VAT reform) was submitted to the Legislative Assembly but is not high on the legislative calendar. The authorities and staff agreed that seeking an early consensus on the need to generate additional revenues would be essential to allow for approval of tax reform early during the term of the next administration.

\section{Achieving low and stable inflation}

\section{The current slowdown, positive terms of trade shock, and sound policies have} combined to reduce inflation to a level not seen in over 30 years. For most of the past decade, Costa Rica's inflation hovered in the low double digits, considerably above the region's average. Staff stressed that the ongoing disinflation provides an opportunity to achieve price stability more rapidly than previously envisaged. Staff and the authorities agreed that advancing in the transition to an inflation targeting regime, supported by greater exchange rate flexibility, could be useful to attain this goal by helping anchor inflation expectations around the central bank's inflation target. However, it was recognized that effecting this change would be challenging and require a considerable communications effort, given entrenched preferences for a crawling peg regime. While acknowledging risks to the inflation outlook, including the unwinding of the drop in energy and food prices, the authorities noted that achieving the end-2010 target of 5 percent would be particularly important for locking in the disinflation gains.

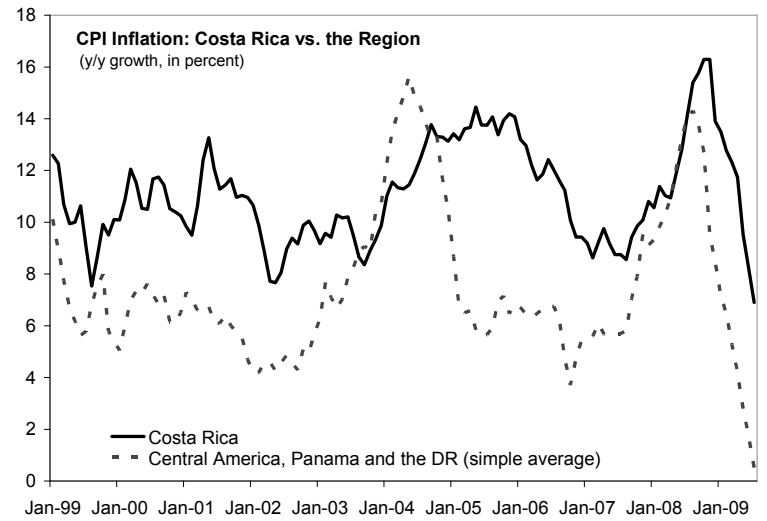

\footnotetext{
${ }^{5}$ The recommendations of the FAD tax policy review include simplifying and eliminating exemptions for the income tax and converting the sales tax into a broad-based value added tax.

${ }^{6}$ Costa Rica's efforts to strengthen tax administration will be supported by a FAD diagnostic mission in September 2009 and the resident tax advisor of the recently established regional IMF technical assistance center (CAPTAC-DR).
} 


\section{Staff argued that monetary policy should be managed more cautiously during the}

transition to inflation targeting. In particular, the central bank should stand ready to sterilize fully the inflationary component of its quasi-fiscal deficit to avoid the large monetary expansions observed in the past. Evidence of inflation persistence also argues for a less accommodative monetary policy stance.

Extensive backward-looking wage indexation, regulated prices, and noncompetitive structures in some key markets with a significant weight in the CPI have contributed to inflation persistence and have been generally validated by higher monetary expansion, complicating monetary policy transmission. Aside from tight monetary control, there was agreement on the desirability of measures that aimed at

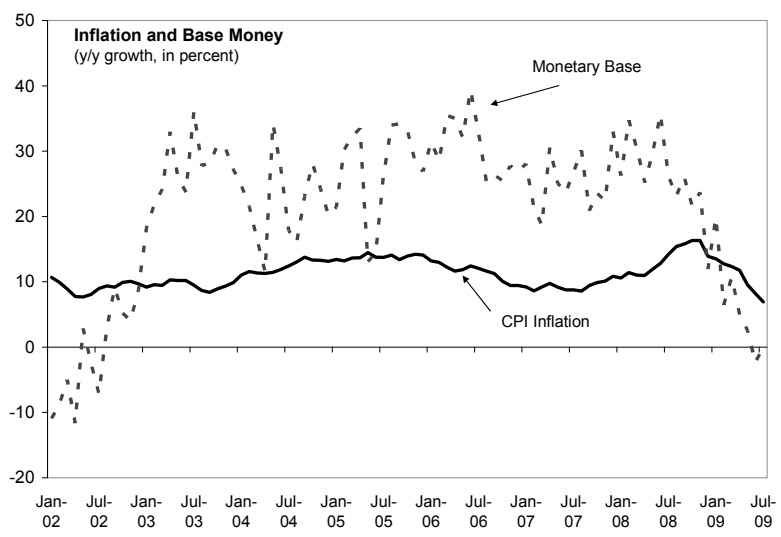
reducing the degree of inflation persistence, such as revising wage setting practices (especially in the public sector), and price-setting in regulated markets, as well as promoting competition in some markets prone to noncompetitive price setting.

\section{Greater exchange rate flexibility and the recapitalization of the BCCR would help} increase the effectiveness of monetary policy. The authorities emphasized that the widening of the currency band is gradually allowing for the exchange rate to move more freely. While the exchange rate has remained close to the upper ceiling of the band during most of 2009, there had been some episodes of appreciation which were helping market participants realize that the exchange rate may fluctuate within the band as external conditions improve. Further episodes of exchange rate fluctuations would provide incentives for market participants to develop instruments to cover for exchange rate risk. Staff suggested that the authorities clarify the BCCR's role in the foreign exchange market to avoid sending mixed signals about its intervention policy. In particular, staff recommended that foreign exchange purchases on behalf of public enterprises be conducted through the banking system rather than the BCCR, and that the BCCR pre-announce its purchases for reserve accumulation purposes. Staff expressed disappointment about the delay in recapitalizing the BCCR, and reiterated the importance of repairing its balance sheet (e.g., through a one-step transfer of negotiable Treasury securities) to enhance monetary control.

\section{Staff proposed several measures to improve the monetary policy framework. Staff} welcomed the integration of the money market under a new platform, which should help better guide short-term market rates toward the BCCR's policy rate and thus enhance monetary policy transmission. In addition, staff proposed that the BCCR eliminate its public deposit-taking facility and conduct its sterilization operations exclusively through its debt operations. Staff argued that this would avoid conflicts between the central bank's deposit structure and its policy stance and increase the central bank's flexibility to absorb liquidity. Refocusing the BCCR's debt management strategy to ensure that liquidity operations are guided by monetary policy objectives rather than cost considerations would also be advisable. 


\section{Reducing external vulnerabilities}

\section{The authorities and staff agreed that the exchange rate is close to its equilibrium}

level. Staff's econometric estimates based on the macro balance and equilibrium real exchange rate approaches suggest that the level of the real effective exchange rate (REER) is broadly in line with fundamentals under the baseline scenario (Box 2). Costa Rica's actual and equilibrium REER have moved in parallel in recent years and even though the actual REER appreciated by about 5 percent in the first half of 2009, it remained well within its error band. The authorities shared this assessment, adding that there is no evidence that export competitiveness has been adversely affected by the crisis. In this regard, they noted that a number of multinational service companies are establishing operations in Costa Rica to take advantage of its competitive labor force for call centers and back-office operations.

\section{Box 2. Assessment of Costa Rica's Real Exchange Rate}

Costa Rica's real exchange rate level is appropriate according to an assessment based on standard methodologies:

- $\quad$ New results from a panel regression of emerging market countries based on the macro balance approach shows that the current account norm for Costa Rica is $43 / 4$ percent of GDP. The current account projection for 2014 of 5 percent of GDP is within two standard errors of this norm. This estimate assumes a fiscal consolidation over the 2011-14 period and a monetary stance that maintains low inflation. Based on these policies, the real exchange rate is assessed to be properly valued.

- In terms of external debt dynamics, the ratio of external debt to GDP is projected to fall modestly over the next few years and stabilize at about 27 percent of GDP. This is slightly below levels normally associated with a sharp rise in crisis probabilities.

- $\quad$ An alternative assessment methodology estimates the long-run determinants of the real exchange rate. Staff and the authorities have found that the real exchange rate in Costa Rica is cointegrated with a small set of variables including the productivity differential between Costa Rica and partner countries, the terms of trade, and Costa Rica's net foreign liability position. These determinants suggest that the real exchange rate was about 5 percent undervalued in 2008 (still within the error bands), but that the subsequent real appreciation in the first half of 2009 has eliminated this differential.

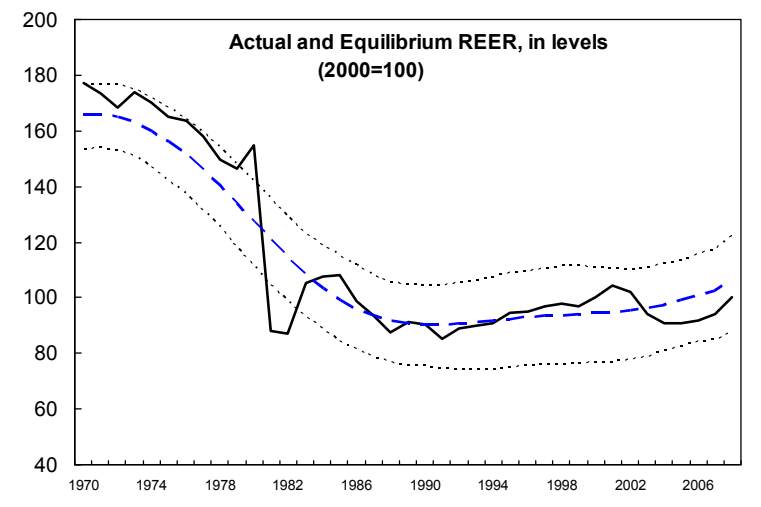


23. Notwithstanding these positive developments, staff stressed that Costa Rica should further strengthen its resilience to external shocks. Increased exchange rate flexibility and higher international reserves would provide greater protection against external shocks. Although Costa Rica's current international reserves coverage is broadly in line with commonly accepted benchmarks, it is somewhat below the coverage levels observed in investment grade countries in the $\mathrm{BBB} / \mathrm{A}$ range and dollarized economies from the region. The authorities reiterated their commitment to continue widening the currency band to provide more room for the colón to float. They also concurred that a gradual further build up of reserves would be desirable, although this would need to be carefully managed so as not to preclude the exchange rate from moving away from the ceiling of the currency band.

Costa Rica: Reserve Coverage Indicators

\begin{tabular}{lrrrr}
\hline & $\begin{array}{c}\text { Reserves/ } \\
\text { Imports of } \\
\text { G+S }\end{array}$ & $\begin{array}{c}\text { Reserves/ } \\
\text { Short-Term } \\
\text { Debt }\end{array}$ & $\begin{array}{c}\text { Reserves/ } \\
\text { GDP }\end{array}$ & $\begin{array}{c}\text { Reserves/ } \\
\text { M2 }\end{array}$ \\
\hline Costa Rica (2010 projection) & 3.0 & 100 & 13.5 & 46 \\
Suggested Threshold & 3.0 & 100 & 10.0 & 20 \\
Median Sample Estimate 1/ & 4.6 & 125 & 20.0 & 30 \\
Median of Dollarized Economies 2/ & 5.6 & 139 & 14.7 & 31 \\
\hline
\end{tabular}

Source: Fund staff computations based on IFS data.

1/ 2005-07 average

2/ Dominican Republic, Guatemala, Peru, Uruguay

\section{Strengthening the financial sector}

24. Staff welcomed the authorities' readiness to step up crisis preparedness and the monitoring of the financial system. As the global financial crisis unfolded, the BCCR and SUGEF sought to boost the system's liquidity, including by modifying regulations to encourage higher liquidity holdings, establishing a temporary facility to increase the liquidity provision to banks, and broadening participation in the interbank money market. In addition, the SUGEF set up a system to detect early symptoms of bank stress, and credit classification rules were eased to facilitate loan workouts. The authorities also boosted the capital of public banks, providing a safety margin ahead of the expected cyclical deterioration of loan portfolios. The authorities and staff agreed that the temporary relaxation of some prudential rules had provided a necessary breather for borrowers, but that banks should generally maintain prudent credit standards, including with regard to safety margins to cover against exchange rate risk.

25. Otherwise, progress in financial sector reforms has been rather slow. While the authorities were successful in discouraging offshore banking activity through tighter regulation (reducing it to virtually zero by end-2008), a key bill to strengthen consolidated bank supervision has yet to be approved by the Legislative Assembly and efforts to strengthen the legal protection of supervisors were derailed by a court ruling. The authorities noted that they will insist on these initiatives and are preparing regulations that will allow to implement consolidated supervision swiftly after its legislative approval. 
26. Staff welcomed the SUGEF's new strategic plan that focuses on implementing a consolidated, risk-based approach to supervision. The authorities noted that the shift to a risk-based approach to supervision would imply considerable changes to supervisory practices, personnel recruitment and training, and enforcement powers and tools. Staff agreed that the transition would need to be gradual and encouraged the authorities to seek technical assistance in this area, including from the IMF.?

\section{The authorities agreed that there remains room to improve bank monitoring and}

data transparency. The SUGEF could improve the collection and processing of information on the maturity structure of bank assets and liabilities and the assessment of liquidity management procedures. In addition, ongoing monitoring efforts should be supplemented with forward-looking stress tests on a bank-by-bank basis, to identify vulnerabilities to key risks. To strengthen market discipline, the SUGEF could further improve the public accessibility and scope of its bank data dissemination. In this context, staff called on the authorities to repeal legal provisions that prohibit the dissemination of key financial soundness indicators for individual banks, including risk-adjusted capital asset ratios.

28. The mission discussed some of the preliminary lessons from the global financial crisis and their relevance for financial sector supervision in Costa Rica. There was agreement that the regulatory perimeter was comprehensive, covering also financial cooperatives and finance companies, and did not leave out any systemically important financial activities. The perimeter has grown with the de-facto closure of the off-shore sector, and would expand further to cover leasing and investment banking operations once the consolidated supervision law was approved. The authorities shared the principle of countercyclical regulation, but indicated that applying it had been a challenge. Therefore, they expressed interest in studying possible instruments being used in other countries. Finally, the authorities noted that the BCCR facility established in late 2008 to provide systemic liquidity would remain in place to deal with future contingencies.

\footnotetext{
${ }^{7}$ The IMF has already been providing technical assistance to the SUGEF to implement a risk-based supervisory framework for anti-money laundering/combating terrorism financing (AML/CFT) purposes.
} 


\section{STAFF APPRAISAL}

29. The Costa Rican economy has withstood the impact of the global economic and financial crisis relatively well. The authorities' strategy to shield the economy from external shocks through fiscal stimulus and the mobilization of contingent external financing, including the precautionary SBA with the Fund, has helped sustain investor confidence and financial stability. Output, especially in sectors dependent on external conditions, has deteriorated sharply, but there is some evidence that the economy is bottoming-out. Performance under the program has been commendable, with the authorities meeting all quantitative performance criteria and structural benchmarks for the first review.

30. Near-term prospects have improved and risks moderated, although they remain somewhat tilted to the downside. Gradually improving global conditions should boost confidence, help lift export-related activities, and restore investor risk appetite. Nonetheless, some possibility of disruptive capital outflows remains, especially if the incipient global recovery falters. This could result in pressures on the colón, which remains close to the ceiling of the currency band.

31. The authorities' program is rightly focused on preserving stability, protecting the external position, and supporting the nascent recovery. In the near term, fiscal policy should aim at balancing the need for maintaining countercyclical support to domestic demand, while keeping domestic government borrowing and the public debt in check. The authorities should take into account that public financing requirements could eventually strain domestic debt markets, contribute to higher real rates and tighter monetary conditions, and disrupt confidence. To avoid this, fiscal consolidation should begin as soon as the recovery takes hold.

32. Inflation has reached historical lows, providing the central bank with an opportunity to achieve durable price stability. Monetary policy will have to maintain its cautious, gradual easing bias conditional on a decline in inflation and devaluation expectations. In particular, continued upward pressure on the exchange rate would limit the room for downward adjustment in nominal interest rates.

33. Although the banking sector is sound, the authorities should remain vigilant to remaining risks and press ahead with their well-focused agenda to strengthen supervision. Further progress to refine early warning systems and identify vulnerabilities to key riskssuch as forward-looking stress testing - should be pursued. Staff welcomes the planned implementation of risk-based supervision and calls for a strengthening of market discipline by modifying legal provisions that limit the dissemination of prudential indicators for individual banks. 
34. Over the medium term, policies should foster attaining sustained growth while limiting domestic and external vulnerabilities. Following the sharp rise in government spending in 2008-10, the fiscal deficit should be reduced to contain vulnerabilities and allow for a gradual reduction in the debt burden. To sustain higher levels of public investment and social services, a substantial increase in tax revenues will be necessary. While further strengthening of tax administration could help boost the tax yield, tax reform should be a central element of the government's strategy. Fostering an early consensus on the need to increase revenues would be essential to ensure that tax reform is approved swiftly.

35. The recent decline in inflation should help strengthen monetary policy credibility and allow important progress in the transition to inflation targeting. Staff regrets the lack of progress in recapitalizing the BCCR, which remains critical for a sustained reduction of inflation as it will remove a key source of monetary expansion in the economy. The authorities are advised to take concrete actions to improve communication and the coherence of the monetary policy framework, including eliminating the BCCR's public deposit-taking facility and conducting sterilization operations exclusively through debt operations; guiding their liquidity operations primarily by monetary policy objectives; and clarifying the BCCR's role in the foreign exchange market.

36. The economy has adjusted rapidly to external shocks but more can be done to strengthen its resilience. The current level of the real effective exchange rate remains broadly consistent with fundamentals. Nonetheless, a further, gradual build up of international reserves over the medium term could provide an extra cushion to the economy and help boost investor confidence.

37. Staff recommends the approval of the first review under the SBA. Performance under the program has been strong, and the authorities' policies appear adequate to support the recovery of the economy, while maintaining internal and external stability.

38. The next Article IV consultation with Costa Rica shall take place in accordance with the July 15, 2002 decision on consultation cycles. 
Table 1. Costa Rica: Selected Economic Indicators 2006-10

\begin{tabular}{|c|c|c|c|c|c|c|c|c|}
\hline \multirow{3}{*}{$\begin{array}{l}\text { Per capita income (2008, U.S. dollars) } \\
\text { Population (July 2008, millions) } \\
\text { Life expectancy (2005, years) }\end{array}$} & \multirow{2}{*}{$\begin{array}{r}6,544 \\
45\end{array}$} & & \multicolumn{5}{|c|}{ Unemployment (2008, percent of labor force) } & \multirow{2}{*}{$\begin{array}{r}4.9 \\
177\end{array}$} \\
\hline & & & \multicolumn{5}{|c|}{ Poverty (2008, percent of households) } & \\
\hline & 79.1 & & \multicolumn{5}{|c|}{ Extreme poverty (2008, percent of households) } & 3.5 \\
\hline & & \multirow[t]{2}{*}{2006} & \multirow[t]{2}{*}{2007} & 2008 & \multirow{2}{*}{\multicolumn{2}{|c|}{$\begin{array}{c}2009 \\
\text { FRS/09/41 }\end{array}$}} & \multicolumn{2}{|c|}{2010} \\
\hline & & & & & & & EBS/09/41 & Proj. \\
\hline
\end{tabular}

\begin{tabular}{|c|c|c|c|c|c|c|c|}
\hline \multirow[b]{2}{*}{ National Income and Prices } & \multicolumn{6}{|c|}{ (Annual percentage change, unless otherwise indicated) } & \multirow[b]{3}{*}{2.3} \\
\hline & & & & & & & \\
\hline GDP at constant prices & 8.8 & 7.8 & 2.6 & 0.5 & -1.5 & 1.5 & \\
\hline Implicit deflator & 11.0 & 9.3 & 12.1 & 10.2 & 8.9 & 7.8 & 6.0 \\
\hline Consumer prices (end of period) & 9.4 & 10.8 & 13.9 & 8.0 & 5.0 & 7.0 & 5.0 \\
\hline \multicolumn{8}{|l|}{ External Sector } \\
\hline Exports of goods (volume, fob) & 10.6 & 9.2 & -3.4 & -7.3 & -6.9 & 3.9 & 2.5 \\
\hline Imports of goods (volume, cif) & 9.3 & 4.1 & 5.8 & -8.9 & -12.3 & 2.9 & 3.1 \\
\hline Terms of trade (deterioration -) & -3.9 & -3.7 & -4.6 & 9.8 & 5.2 & -2.8 & -2.3 \\
\hline Real Effective Exchange Rate (eop; depreciation -) & 0.9 & 2.8 & 5.4 & $\ldots$ & $\ldots$ & $\ldots$ & $\ldots$ \\
\hline \multicolumn{8}{|l|}{ Money and Credit } \\
\hline Base money & 26.9 & 33.0 & 11.9 & 7.1 & 7.7 & 8.5 & 10.0 \\
\hline Broad money & 25.3 & 16.3 & 17.3 & 11.8 & 15.6 & 9.6 & 12.8 \\
\hline Bank credit to private sector & 28.5 & 38.3 & 31.8 & 9.2 & 4.7 & 10.7 & 12.7 \\
\hline Lending interest rate (end of period) & 20.7 & 16.3 & 20.7 & $\ldots$ & $\ldots$ & $\ldots$ & $\ldots$ \\
\hline \multicolumn{8}{|c|}{ (In percent of GDP) } \\
\hline Public Finances & & & & & & & \\
\hline Combined public sector primary balance $1 /$ & 2.8 & 4.1 & 2.3 & -1.5 & -2.4 & -1.3 & -2.3 \\
\hline Combined public sector overall balance $1 /$ & -0.7 & 1.2 & 0.1 & -4.1 & -4.8 & -4.1 & -4.7 \\
\hline Central government balance & -1.4 & 0.3 & -0.3 & -3.2 & -4.1 & -3.2 & -4.1 \\
\hline Social security balance & 1.9 & 1.2 & 0.6 & 0.3 & 0.2 & 0.2 & 0.1 \\
\hline Central bank balance & -1.1 & -0.7 & -0.2 & -1.0 & -0.8 & -1.0 & -0.6 \\
\hline Other public enterprises and entities balance & 0.0 & 0.4 & 0.0 & -0.1 & -0.1 & -0.1 & 0.0 \\
\hline Combined public sector debt (gross) $1 /$ & 47.8 & 43.2 & 35.8 & 36.9 & 39.9 & 38.3 & 41.6 \\
\hline Of which: External public debt & 13.1 & 10.5 & 9.1 & 9.1 & 8.3 & 10.0 & 9.3 \\
\hline \multicolumn{8}{|l|}{ Savings and Investment } \\
\hline Gross domestic investment & 26.4 & 24.6 & 25.8 & 21.4 & 17.1 & 21.2 & 18.8 \\
\hline Gross national savings & 21.3 & 18.3 & 16.6 & 16.1 & 13.5 & 15.9 & 13.9 \\
\hline \multicolumn{8}{|l|}{ External Sector } \\
\hline Trade balance & -12.7 & -11.4 & -16.8 & -11.3 & -10.2 & -11.5 & -11.3 \\
\hline Current account balance & -5.1 & -6.3 & -9.2 & -5.3 & -3.6 & -5.3 & -4.8 \\
\hline \multirow[t]{2}{*}{ Foreign direct investment } & 6.1 & 6.2 & 6.8 & 4.7 & 4.3 & 4.6 & 4.7 \\
\hline & \multicolumn{6}{|c|}{ (In millions of U.S. dollars, unless otherwise indicated) } & \\
\hline Change in net international reserves (increase -) & $-1,034$ & -839 & 315 & 0 & 0 & -100 & -100 \\
\hline Net international reserves $2 /$ & 3,115 & 4,114 & 3,799 & 3,799 & 4,004 & 3,899 & 4,104 \\
\hline -in months of nonmaquila imports & 3.4 & 3.6 & 4.2 & 3.9 & 4.1 & 3.8 & 4.0 \\
\hline Gross Domestic Product & 22,528 & 26,269 & 29,664 & 30,177 & 29,291 & 31,042 & 30,433 \\
\hline
\end{tabular}

Sources: Central Bank of Costa Rica; Ministry of Finance; and Fund staff projections.

1/ Combined Public sector $=$ Central government + Central bank + Other public enterprises and entities, excluding ICE .

$2 /$ Includes valuation adjustments of US\$160 million in 2007 for reclassification of capital contribution to FLAR and US\$205 million in 2009 for SDR allocation. 
Table 2. Costa Rica: Balance of Payments 2006-10

(In millions of U.S. dollars, unless otherwise indicated)

\begin{tabular}{|c|c|c|c|c|c|c|c|}
\hline & \multirow[t]{2}{*}{2006} & \multirow[t]{2}{*}{2007} & \multirow[t]{2}{*}{2008} & \multicolumn{2}{|c|}{2009} & \multicolumn{2}{|c|}{2010} \\
\hline & & & & EBS/09/41 & Proj. & $\mathrm{EBS} / 09 / 41$ & Proj. \\
\hline Current Account & $-1,151$ & $-1,647$ & $-2,728$ & $-1,602$ & $-1,057$ & $-1,656$ & $-1,474$ \\
\hline Trade balance & $-2,856$ & $-2,986$ & $-4,984$ & $-3,225$ & $-2,979$ & $-3,426$ & $-3,439$ \\
\hline Trade balance goods for processing & 769 & 1,722 & 2,202 & 2,138 & 2,175 & 2,089 & 2,239 \\
\hline Export of goods (f.o.b.) & 8,102 & 9,300 & 9,566 & 8,577 & 8,798 & 9,054 & 9,132 \\
\hline General merchandise and others & 3,829 & 4,312 & 4,339 & 3,824 & 3,859 & 4,080 & 4,044 \\
\hline Goods for processing & 4,273 & 4,988 & 5,227 & 4,752 & 4,939 & 4,975 & 5,088 \\
\hline Import of goods (f.o.b.) & 10,957 & 12,285 & 14,550 & 11,802 & 11,777 & 12,481 & 12,571 \\
\hline General merchandise and others & 7,454 & 9,019 & 11,524 & 9,188 & 9,012 & 9,595 & 9,721 \\
\hline Oil products & 1,250 & 1,343 & 2,089 & 1,023 & 1,254 & 1,165 & 1,571 \\
\hline Others & 6,205 & 7,677 & 9,436 & 8,165 & 7,758 & 8,431 & 8,151 \\
\hline Goods for processing & 3,503 & 3,266 & 3,026 & 2,614 & 2,765 & 2,885 & 2,849 \\
\hline Services & 1,351 & 1,733 & 2,202 & 1,995 & 2,002 & 2,174 & 2,118 \\
\hline Of which: Travel & 1,222 & 1,392 & 1,683 & 1,465 & 1,442 & 1,614 & 1,554 \\
\hline Income & 4 & -865 & -389 & -859 & -491 & -902 & -517 \\
\hline Of which: Interest on external public debt & -160 & -177 & -180 & -189 & -191 & -206 & -175 \\
\hline Of which: FDI income, net & -113 & -998 & -442 & -971 & -450 & $-1,101$ & -605 \\
\hline Current transfers & 349 & 470 & 442 & 488 & 411 & 498 & 364 \\
\hline Financial and Capital Account & 2,038 & 2,289 & 2,411 & 1,602 & 1,057 & 1,756 & 1,574 \\
\hline Direct investment & 1,371 & 1,634 & 2,015 & 1,334 & 1,270 & 1,353 & 1,420 \\
\hline Capital flows & 667 & 656 & 396 & 268 & -213 & 403 & 154 \\
\hline Public sector & -157 & -72 & 11 & 197 & 104 & 481 & 457 \\
\hline Disbursements & 129 & 231 & 737 & 703 & 577 & 628 & 673 \\
\hline Amortization (inc. changes in PE deposits) & -285 & -303 & -726 & -507 & -473 & -147 & -216 \\
\hline Private net capital & 823 & 728 & 385 & 71 & -317 & -77 & -303 \\
\hline Of which: Commercial banks & 66 & 830 & 159 & 68 & -711 & 0 & 0 \\
\hline Of which: Private nonfinancial sector & 757 & -103 & 226 & 4 & 393 & -77 & -303 \\
\hline Errors and Omissions & 148 & 197 & 3 & 0 & 0 & 0 & 0 \\
\hline \multirow[t]{2}{*}{ Change in Net Reserves (increase -) } & $-1,034$ & -839 & 315 & 0 & 0 & -100 & -100 \\
\hline & \multicolumn{7}{|c|}{ (Annual percentage change) } \\
\hline Export of Goods (f.o.b.) & & & & & & & \\
\hline Value & 14.1 & 14.8 & 2.9 & -10.4 & -8.0 & 5.6 & 3.8 \\
\hline Volume & 10.6 & 9.2 & -3.4 & -7.3 & -6.9 & 3.9 & 2.5 \\
\hline \multicolumn{8}{|l|}{ Import of Goods (c.i.f.) } \\
\hline Value & 16.3 & 11.5 & 18.1 & -19.8 & -18.4 & 5.2 & 5.9 \\
\hline Volume & 9.3 & 4.1 & 5.8 & -8.9 & -12.3 & 2.9 & 3.1 \\
\hline \multicolumn{8}{|l|}{ Of which: oil } \\
\hline Value & 25.2 & 7.4 & 55.6 & -51.0 & -40.0 & 19.5 & 25.3 \\
\hline \multirow[t]{2}{*}{ Volume } & 8.7 & 4.4 & 7.1 & 0.0 & -8.8 & 1.5 & 8.2 \\
\hline & \multicolumn{7}{|c|}{ (In percent of GDP) } \\
\hline Current account & -5.1 & -6.3 & -9.2 & -5.3 & -3.6 & -5.3 & -4.8 \\
\hline Non-oil current account & 0.4 & -1.2 & -2.2 & -1.9 & 0.7 & -1.4 & 0.3 \\
\hline Export of goods (f.o.b.) & 36.0 & 35.4 & 32.2 & 28.4 & 30.0 & 29.2 & 30.0 \\
\hline Import of goods (f.o.b.) & 48.6 & 46.8 & 49.1 & 39.1 & 40.2 & 40.2 & 41.3 \\
\hline Non-oil goods imports (f.o.b.) & 43.1 & 41.7 & 42.0 & 35.7 & 35.9 & 36.3 & 36.1 \\
\hline Income & 0.0 & -3.3 & -1.3 & -2.8 & -1.7 & -2.9 & -1.7 \\
\hline Direct investment & 6.1 & 6.2 & 6.8 & 4.4 & 4.3 & 4.4 & 4.7 \\
\hline \multicolumn{8}{|l|}{ Memorandum Items: } \\
\hline Net international reserves (US\$ million) 1/ & 3,115 & 4,114 & 3,799 & 3,799 & 4,004 & 3,899 & 4,104 \\
\hline -in months of non-maquila imports & 3.4 & 3.6 & 4.2 & 3.9 & 4.1 & 3.8 & 4.0 \\
\hline -in percent short-term debt $2 /$ & 108.2 & 97.2 & 79.1 & 91.6 & 104.2 & 97.0 & 100.2 \\
\hline External debt $3 /$ & 31.0 & 31.8 & 31.0 & 30.6 & 31.3 & 31.0 & 30.3 \\
\hline
\end{tabular}

Sources: Central Bank of Costa Rica; and Fund staff estimates.

$1 /$ Includes valuation adjustments of US\$160 million in 2007 for reclassification of capital contribution to FLAR and US\$205 million in 2009 for new SDR allocation.

2/ Public and private sector external debt on remaining maturity. Includes trade credits.

$3 /$ Includes public and private sector debt. 
Table 3. Costa Rica: Central Government Balance 2006-10

(In percent of GDP)

\begin{tabular}{|c|c|c|c|c|c|c|c|}
\hline & \multirow[t]{2}{*}{2006} & \multirow[t]{2}{*}{2007} & \multirow[t]{2}{*}{2008} & \multicolumn{2}{|c|}{2009} & \multicolumn{2}{|c|}{2010} \\
\hline & & & & EBS/09/41 & Proj. & EBS/09/41 & Proj. \\
\hline Revenue & 14.2 & 15.5 & 15.9 & 15.7 & 14.5 & 15.8 & 15.2 \\
\hline Tax revenue & 14.0 & 15.2 & 15.7 & 15.4 & 14.3 & 15.6 & 14.9 \\
\hline Direct taxes & 4.0 & 4.6 & 5.1 & 4.9 & 4.6 & 5.0 & 5.1 \\
\hline Sales tax & 5.4 & 5.9 & 6.0 & 6.0 & 5.4 & 5.9 & 5.5 \\
\hline Excise, customs, and others & 4.5 & 4.8 & 4.6 & 4.5 & 4.2 & 4.6 & 4.3 \\
\hline Nontax revenue & 0.2 & 0.3 & 0.2 & 0.2 & 0.3 & 0.3 & 0.3 \\
\hline Expenditure & 15.7 & 15.2 & 16.2 & 18.9 & 18.6 & 19.0 & 19.4 \\
\hline Current noninterest & 10.5 & 10.5 & 11.4 & 13.7 & 13.9 & 13.8 & 14.4 \\
\hline Wages and salaries & 4.6 & 4.4 & 4.6 & 5.6 & 5.8 & 6.0 & 6.0 \\
\hline Pensions and social security & 2.4 & 2.4 & 2.4 & 2.6 & 2.7 & 2.7 & 2.7 \\
\hline Transfers and other & 3.4 & 3.7 & 4.4 & 5.5 & 5.5 & 5.1 & 5.7 \\
\hline Interest & 4.2 & 3.3 & 2.7 & 2.6 & 2.6 & 2.9 & 2.9 \\
\hline o/w adjustment for TUDES 1/ & 0.4 & 0.3 & 0.5 & 0.4 & 0.2 & 0.4 & 0.3 \\
\hline Capital & 1.0 & 1.3 & 1.8 & 2.6 & 2.1 & 2.3 & 2.1 \\
\hline Recapitalization of commercial banks & 0.0 & 0.0 & 0.4 & 0.0 & 0.0 & 0.0 & 0.0 \\
\hline Primary balance & 2.7 & 3.7 & 2.4 & -0.6 & -1.5 & -0.3 & -1.2 \\
\hline Structural primary balance 2/ & 2.4 & 2.7 & 2.0 & -0.4 & -1.3 & 0.4 & -0.8 \\
\hline Overall Balance & -1.4 & 0.3 & -0.3 & -3.2 & -4.1 & -3.2 & -4.1 \\
\hline Structural overall balance 2/ & -1.8 & -0.6 & -0.6 & -3.0 & -3.9 & -2.5 & -3.7 \\
\hline Total Financing & 1.4 & -0.3 & 0.3 & 3.2 & 4.1 & 3.2 & 4.1 \\
\hline External (net) & -0.2 & -0.2 & -0.2 & 0.3 & -0.6 & 1.2 & 1.5 \\
\hline Internal (net) & 1.7 & -0.2 & 0.5 & 2.9 & 4.7 & 2.0 & 2.7 \\
\hline \multicolumn{8}{|l|}{ Memorandum Items: } \\
\hline Central government debt & 33.3 & 27.6 & 24.9 & 26.1 & 28.9 & 27.4 & 31.0 \\
\hline External & 10.4 & 8.4 & 7.8 & 7.8 & 7.1 & 8.8 & 8.2 \\
\hline Domestic & 22.9 & 19.2 & 17.1 & 18.2 & 21.8 & 18.7 & 22.8 \\
\hline
\end{tabular}

Sources: Ministry of Finance; and Fund staff estimates.

1/ TUDES are inflation indexed bonds of the central government. The inflation adjustment of principal is not reflected as interest expenditure in the fiscal accounts of the Costa Rican authorities, but is added here to the Fund presentation of the fiscal deficit and public sector debt.

2/ For 2008, excludes one time expense for recapitalization of commercial banks. 
Table 4. Costa Rica: Central Government Balance 2006-10

(In billions of colones)

\begin{tabular}{|c|c|c|c|c|c|c|c|}
\hline & \multirow[t]{2}{*}{2006} & \multirow[t]{2}{*}{2007} & \multirow[t]{2}{*}{2008} & \multicolumn{2}{|c|}{2009} & \multicolumn{2}{|c|}{2010} \\
\hline & & & & EBS/09/41 & Proj. & EBS/09/41 & Proj. \\
\hline Revenue & 1,639 & 2,105 & 2,490 & 2,722 & 2,432 & 3,012 & 2,764 \\
\hline Tax Revenue & 1,612 & 2,067 & 2,453 & 2,679 & 2,389 & 2,965 & 2,713 \\
\hline Direct taxes & 465 & 622 & 801 & 853 & 774 & 956 & 936 \\
\hline Sales tax & 627 & 798 & 937 & 1,037 & 906 & 1,130 & 1,000 \\
\hline Excise, customs, and others & 520 & 647 & 715 & 789 & 709 & 879 & 778 \\
\hline Nontax Revenue & 27 & 38 & 37 & 43 & 43 & 48 & 51 \\
\hline Expenditure & 1,804 & 2,062 & 2,535 & 3,280 & 3,112 & 3,625 & 3,517 \\
\hline Current noninterest & 1,212 & 1,427 & 1,776 & 2,377 & 2,335 & 2,630 & 2,610 \\
\hline Wages and salaries & 535 & 601 & 721 & 967 & 965 & 1,135 & 1,090 \\
\hline Pensions and social security & 282 & 324 & 372 & 449 & 448 & 516 & 488 \\
\hline Transfers and other & 396 & 503 & 683 & 961 & 922 & 979 & 1,032 \\
\hline Interest & 482 & 454 & 415 & 457 & 432 & 550 & 527 \\
\hline Of which: adjustment for TUDES 1/ & 45 & 35 & 75 & 66 & 41 & 80 & 60 \\
\hline Capital & 110 & 180 & 279 & 446 & 345 & 445 & 381 \\
\hline Recapitalization of commercial banks & 0 & 0 & 65 & 0 & 0 & 0 & 0 \\
\hline Primary balance & 316 & 497 & 370 & -101 & -248 & -63 & -226 \\
\hline Structural primary balance 2/ & 274 & 370 & 320 & -67 & -219 & 79 & -143 \\
\hline Overall Balance & -165 & 43 & -45 & -558 & -680 & -613 & -753 \\
\hline Structural overall balance 2/ & -207 & -84 & -95 & -524 & -651 & -470 & -670 \\
\hline Total Financing & 165 & -43 & 45 & 558 & 680 & 613 & 753 \\
\hline External (net) & -27 & -21 & -39 & 56 & -109 & 225 & 264 \\
\hline Internal (net) & 192 & -22 & 84 & 502 & 789 & 387 & 489 \\
\hline \multicolumn{8}{|l|}{ Memorandum Items: } \\
\hline Central government debt & 3,837 & 3,744 & 3,885 & 4,534 & 4,843 & 5,220 & 5,631 \\
\hline External & 1,202 & 1,135 & 1,222 & 1,364 & 1,183 & 1,669 & 1,485 \\
\hline Domestic & 2,636 & 2,610 & 2,663 & 3,170 & 3,660 & 3,551 & 4,146 \\
\hline
\end{tabular}

Sources: Ministry of Finance; and Fund staff estimates.

1/ TUDES are inflation indexed bonds of the central government. The inflation adjustment of principal is not reflected as interest expenditure in the fiscal accounts of the Costa Rican authorities, but is added here to the Fund presentation of the fiscal deficit and public sector debt.

2/ For 2008, excludes one time expense for recapitalization of commercial banks. 
Table 5. Costa Rica: Combined Public Sector Operations 2006-10 $1 /$

(In percent of GDP)

\begin{tabular}{|c|c|c|c|c|c|c|c|}
\hline & \multirow[t]{2}{*}{2006} & \multirow[t]{2}{*}{2007} & \multirow[t]{2}{*}{2008} & \multicolumn{2}{|c|}{2009} & \multicolumn{2}{|c|}{2010} \\
\hline & & & & $\overline{\mathrm{EBS} / 09 / 41}$ & Proj. & EBS/09/41 & Proj. \\
\hline Revenues & 21.2 & 22.8 & 23.3 & 23.0 & 22.2 & 23.5 & 23.3 \\
\hline Tax revenue & 14.0 & 15.2 & 15.7 & 15.4 & 14.3 & 15.6 & 14.9 \\
\hline Direct taxes & 4.0 & 4.6 & 5.1 & 4.9 & 4.6 & 5.0 & 5.1 \\
\hline Sales tax & 5.4 & 5.9 & 6.0 & 6.0 & 5.4 & 5.9 & 5.5 \\
\hline Excise, customs, and others & 4.5 & 4.8 & 4.6 & 4.5 & 4.2 & 4.6 & 4.3 \\
\hline Nontax revenue & 0.2 & 0.3 & 0.2 & 0.2 & 0.3 & 0.3 & 0.3 \\
\hline Contributions to social security & 6.2 & 6.3 & 6.8 & 6.8 & 7.1 & 7.1 & 7.5 \\
\hline Operating balance of public enterprises & 0.7 & 1.0 & 0.6 & 0.5 & 0.6 & 0.5 & 0.6 \\
\hline Noninterest expenditure & 18.4 & 18.8 & 21.0 & 24.5 & 24.6 & 24.8 & 25.6 \\
\hline Wages and salaries & 7.2 & 7.1 & 7.5 & 8.6 & 8.9 & 9.3 & 9.4 \\
\hline Goods and services & 1.8 & 2.0 & 2.1 & 2.3 & 2.4 & 2.1 & 2.2 \\
\hline Pensions & 4.4 & 4.4 & 4.6 & 5.0 & 5.2 & 5.3 & 5.6 \\
\hline Transfers & 2.9 & 3.2 & 3.8 & 4.8 & 4.7 & 4.6 & 5.1 \\
\hline Central Bank primary losses & 0.2 & 0.0 & -0.2 & 0.0 & 0.0 & 0.0 & 0.1 \\
\hline Net capital expenditure & 1.9 & 2.1 & 3.2 & 3.8 & 3.3 & 3.5 & 3.2 \\
\hline Central Government (incl. capital transfers) & 1.0 & 1.3 & 2.2 & 2.6 & 2.1 & 2.3 & 2.1 \\
\hline Rest of the Nonfinancial Public Sector & 0.9 & 0.8 & 1.0 & 1.2 & 1.3 & 1.1 & 1.1 \\
\hline Primary balance & 2.8 & 4.1 & 2.3 & -1.5 & -2.4 & -1.3 & -2.3 \\
\hline Net interest expenditure & 3.4 & 2.9 & 2.1 & 2.6 & 2.4 & 2.8 & 2.4 \\
\hline Overall Balance & -0.7 & 1.2 & 0.1 & -4.1 & -4.8 & -4.1 & -4.7 \\
\hline Central government & -1.4 & 0.3 & -0.3 & -3.2 & -4.1 & -3.2 & -4.1 \\
\hline of which : Adjustment for TUDES $2 /$ & -0.4 & -0.3 & -0.5 & -0.4 & -0.2 & -0.4 & -0.3 \\
\hline Social Security Agency & 1.9 & 1.2 & 0.6 & 0.3 & 0.2 & 0.2 & 0.1 \\
\hline of which: Adjustment for TUDES 2/ & 0.3 & 0.3 & 0.2 & 0.2 & 0.1 & 0.2 & 0.1 \\
\hline Other public enterprises and entities & 0.0 & 0.4 & 0.0 & -0.1 & -0.1 & -0.1 & 0.0 \\
\hline Central bank & -1.1 & -0.7 & -0.2 & -1.0 & -0.8 & -1.0 & -0.6 \\
\hline Total Financing & 0.7 & -1.2 & -0.1 & 4.1 & 4.8 & 4.1 & 4.7 \\
\hline External & -0.1 & -0.2 & -0.2 & 0.4 & -0.3 & 1.2 & 1.6 \\
\hline Internal & 0.7 & -1.0 & 0.0 & 3.7 & 5.1 & 2.9 & 3.1 \\
\hline \multicolumn{8}{|l|}{ Memorandum items: } \\
\hline Total combined public sector debt & 47.8 & 43.2 & 35.8 & 36.9 & 39.9 & 38.3 & 41.6 \\
\hline External & 13.1 & 10.5 & 9.1 & 9.1 & 8.3 & 10.0 & 9.3 \\
\hline Domestic & 34.6 & 32.7 & 26.8 & 27.8 & 31.6 & 28.3 & 32.3 \\
\hline
\end{tabular}

Sources: Ministry of Finance; and Fund staff estimates.

1/ Combined Public sector $=$ Central government + Central bank + Other public enterprises and entities (excluding ICE).

2/ TUDES are inflation indexed bonds of the central government. The inflation adjustment of principal is not reflected as interest expenditure in the fiscal accounts of the Costa Rican authorities, but is added here to the Fund presentation of the fiscal deficit and public sector debt. 
Table 6. Costa Rica: Combined Public Sector Operations 2006-10 1/

(In billions of colones)

\begin{tabular}{|c|c|c|c|c|c|c|c|}
\hline & \multirow[t]{2}{*}{2006} & \multirow[t]{2}{*}{2007} & \multirow[t]{2}{*}{2008} & \multicolumn{2}{|c|}{2009} & \multicolumn{2}{|c|}{2010} \\
\hline & & & & $\overline{\mathrm{EBS} / 09 / 41}$ & Proj. & EBS/09/41 & Proj. \\
\hline Revenues & 2,437 & 3,098 & 3,635 & 3,998 & 3,718 & 4,466 & 4,243 \\
\hline Tax revenue & 1,612 & 2,067 & 2,453 & 2,679 & 2,389 & 2,965 & 2,713 \\
\hline Direct taxes & 465 & 622 & 801 & 853 & 774 & 956 & 936 \\
\hline Sales tax & 627 & 798 & 937 & 1,037 & 906 & 1,130 & 1,000 \\
\hline Excise, customs, and others & 520 & 647 & 715 & 789 & 709 & 879 & 778 \\
\hline Nontax revenue & 27 & 38 & 37 & 43 & 43 & 48 & 51 \\
\hline Contributions to social security & 715 & 855 & 1,057 & 1,183 & 1,190 & 1,350 & 1,371 \\
\hline Operating balance of public enterprises & 84 & 139 & 89 & 93 & 96 & 104 & 108 \\
\hline Noninterest expenditure & 2,119 & 2,547 & 3,279 & 4,258 & 4,120 & 4,714 & 4,658 \\
\hline Wages and salaries & 829 & 959 & 1,165 & 1,500 & 1,498 & 1,763 & 1,717 \\
\hline Goods and services & 211 & 266 & 321 & 404 & 404 & 405 & 405 \\
\hline Pensions & 506 & 597 & 719 & 868 & 877 & 1,010 & 1,011 \\
\hline Transfers & 340 & 430 & 596 & 827 & 787 & 879 & 932 \\
\hline Central Bank primary losses & 17 & 5 & -27 & 3 & -2 & -1 & 13 \\
\hline Net capital expenditure & 216 & 290 & 505 & 656 & 555 & 658 & 580 \\
\hline Central Government (incl. capital transfers) & 110 & 180 & 344 & 446 & 345 & 445 & 381 \\
\hline Rest of the Nonfinancial Public Sector & 106 & 110 & 161 & 210 & 210 & 213 & 200 \\
\hline Primary balance & 317 & 552 & 357 & -260 & -402 & -248 & -415 \\
\hline Net interest expenditure & 394 & 388 & 334 & 447 & 394 & 539 & 432 \\
\hline Overall Balance & -77 & 164 & 23 & -708 & -796 & -787 & -847 \\
\hline Central government & -165 & 43 & -45 & -558 & -680 & -613 & -753 \\
\hline of which: Adjustment for TUDES 2/ & -45 & -35 & -75 & -66 & -41 & -80 & -60 \\
\hline Social Security Agency & 218 & 160 & 101 & 47 & 36 & 37 & 10 \\
\hline of which: Adjustment for TUDES 2/ & 35 & 37 & 34 & 30 & 19 & 36 & 27 \\
\hline Other public enterprises and entities & 2 & 57 & -4 & -25 & -25 & -25 & 6 \\
\hline Central bank & -131 & -96 & -29 & -172 & -127 & -186 & -110 \\
\hline Total Financing & 77 & -164 & -23 & 708 & 796 & 787 & 847 \\
\hline External & -6 & -23 & -26 & 62 & -54 & 226 & 284 \\
\hline Internal & 83 & -141 & 3 & 646 & 851 & 561 & 563 \\
\hline \multicolumn{8}{|l|}{ Memorandum items: } \\
\hline Total combined public sector debt & 5,502 & 5,869 & 5,596 & 6,421 & 6,681 & 7,293 & 7,569 \\
\hline External & 1,513 & 1,425 & 1,414 & 1,583 & 1,387 & 1,909 & 1,698 \\
\hline Domestic & 3,989 & 4,444 & 4,182 & 4,837 & 5,293 & 5,384 & 5,871 \\
\hline
\end{tabular}

Sources: Ministry of Finance; and Fund staff estimates.

1/ Combined public sector $=$ Central government + Central bank + Other public enterprises and entities (excluding ICE).

2/ TUDES are inflation indexed bonds of the central government. The inflation adjustment of principal is not reflected as interest expenditure in the fiscal accounts of the Costa Rican authorities, but is added here to the Fund presentation of the fiscal deficit and public sector debt. 
Table 7. Costa Rica: Monetary Survey 2006-10

(In billions of colones)

\begin{tabular}{|c|c|c|c|c|c|c|c|}
\hline & \multirow[t]{2}{*}{2006} & \multirow[t]{2}{*}{2007} & \multirow[t]{2}{*}{2008} & \multicolumn{2}{|c|}{2009} & \multicolumn{2}{|c|}{2010} \\
\hline & & & & EBS/09/41 & Proj. & EBS/09/41 & Proj. \\
\hline \multicolumn{8}{|l|}{ Central Bank } \\
\hline Net foreign assets & 1,626 & 2,144 & 2,206 & 2,389 & 2,475 & 2,603 & 2,630 \\
\hline $\begin{array}{c}\text { Net international reserves } \\
\text { (In millions of US\$) }\end{array}$ & $\begin{array}{l}1,607 \\
3,115\end{array}$ & $\begin{array}{l}2,037 \\
4,114\end{array}$ & $\begin{array}{l}2,090 \\
3,799\end{array}$ & $\begin{array}{l}2,249 \\
3,799\end{array}$ & $\begin{array}{l}2,337 \\
4,004\end{array}$ & $\begin{array}{l}2,454 \\
3,899\end{array}$ & $\begin{array}{l}2,487 \\
4,104\end{array}$ \\
\hline $\begin{array}{l}\text { Net domestic assets } \\
\text { Net domestic credit } \\
\text { Credit to the Nonfinancial Public Sector } \\
\text { Credit to Other Depository Corporations (net) } \\
\text { Credit to Other Financial Corporations (net) } \\
\text { Credit to the Private Sector (net) } \\
\text { Capital account (-) } \\
\text { Other items net (-) } \\
\text { Monetary stabilization bonds (-) }\end{array}$ & $\begin{array}{r}-853 \\
-412 \\
-48 \\
-361 \\
-1 \\
-1 \\
1,120 \\
-137 \\
-1,424\end{array}$ & $\begin{array}{r}-1,116 \\
-444 \\
-64 \\
-380 \\
2 \\
-2 \\
1,163 \\
7 \\
-1,842\end{array}$ & $\begin{array}{r}-1,055 \\
-547 \\
-20 \\
-525 \\
0 \\
-2 \\
1,199 \\
-254 \\
-1,453\end{array}$ & $\begin{array}{r}-1,157 \\
-622 \\
-32 \\
-588 \\
0 \\
-2 \\
1,369 \\
-283 \\
-1,621\end{array}$ & $\begin{array}{r}-1,236 \\
-835 \\
-94 \\
-735 \\
-3 \\
-2 \\
1,336 \\
-339 \\
-1,398\end{array}$ & $\begin{array}{r}-1,265 \\
-697 \\
-30 \\
-664 \\
0 \\
-2 \\
1,280 \\
-283 \\
-1,565\end{array}$ & $\begin{array}{r}-1,266 \\
-835 \\
16 \\
-846 \\
-3 \\
-2 \\
1,303 \\
-339 \\
-1,395\end{array}$ \\
\hline $\begin{array}{l}\text { Monetary base } \\
\text { Currency } \\
\text { Required reserves }\end{array}$ & $\begin{array}{l}773 \\
413 \\
360\end{array}$ & $\begin{array}{r}1,028 \\
546 \\
482\end{array}$ & $\begin{array}{r}1,151 \\
575 \\
576\end{array}$ & $\begin{array}{r}1,233 \\
631 \\
602\end{array}$ & $\begin{array}{r}1,240 \\
623 \\
616\end{array}$ & $\begin{array}{r}1,338 \\
680 \\
659\end{array}$ & $\begin{array}{r}1,364 \\
683 \\
681\end{array}$ \\
\hline \multicolumn{8}{|l|}{ Other Depository Institutions } \\
\hline $\begin{array}{l}\text { Net domestic assets } \\
\text { Net domestic credit } \\
\text { Credit to nonfinancial public sector (net) } \\
\text { Credit to the private sector } \\
\text { Credit to financial corporations (net) } \\
\text { Capital account } \\
\text { Other items (net) }\end{array}$ & $\begin{array}{r}4,980 \\
6,488 \\
541 \\
4,347 \\
1,600 \\
1,037 \\
-472\end{array}$ & $\begin{array}{r}6,250 \\
8,097 \\
338 \\
6,014 \\
1,746 \\
1,237 \\
-609\end{array}$ & $\begin{array}{r}7,796 \\
10,064 \\
316 \\
7,926 \\
1,823 \\
1,597 \\
-671\end{array}$ & $\begin{array}{r}8,419 \\
10,812 \\
319 \\
8,588 \\
1,904 \\
1,692 \\
-701\end{array}$ & $\begin{array}{r}8,732 \\
11,042 \\
559 \\
8,302 \\
2,181 \\
1,656 \\
-653\end{array}$ & $\begin{array}{r}9,342 \\
11,848 \\
309 \\
9,504 \\
2,035 \\
1,805 \\
-701\end{array}$ & $\begin{array}{r}9,977 \\
12,348 \\
682 \\
9,356 \\
2,310 \\
1,717 \\
-653\end{array}$ \\
\hline $\begin{array}{l}\text { Liabilities } \\
\text { National currency } \\
\text { Foreign currency }\end{array}$ & $\begin{array}{l}5,046 \\
2,673 \\
2,373\end{array}$ & $\begin{array}{l}5,904 \\
3,502 \\
2,402\end{array}$ & $\begin{array}{l}7,323 \\
3,950 \\
3,373\end{array}$ & $\begin{array}{l}8,230 \\
4,420 \\
3,810\end{array}$ & $\begin{array}{l}8,645 \\
4,481 \\
4,164\end{array}$ & $\begin{array}{l}9,142 \\
4,838 \\
4,304\end{array}$ & $\begin{array}{l}9,887 \\
5,097 \\
4,790\end{array}$ \\
\hline \multicolumn{8}{|l|}{ Financial System } \\
\hline $\begin{array}{l}\text { Net domestic assets } \\
\text { Net domestic credit } \\
\text { Capital account } \\
\text { Other items (net) }\end{array}$ & $\begin{array}{r}4,592 \\
4,840 \\
-83 \\
-332\end{array}$ & $\begin{array}{r}5,549 \\
6,287 \\
74 \\
-664\end{array}$ & $\begin{array}{r}6,885 \\
8,221 \\
398 \\
-938\end{array}$ & $\begin{array}{r}7,527 \\
8,876 \\
323 \\
-1,026\end{array}$ & $\begin{array}{r}7,600 \\
8,766 \\
320 \\
-846\end{array}$ & $\begin{array}{r}8,266 \\
9,783 \\
525 \\
-992\end{array}$ & $\begin{array}{r}8,732 \\
10,054 \\
414 \\
-908\end{array}$ \\
\hline Broad money (M4) & 6,381 & 7,423 & 8,709 & 9,815 & 10,067 & 10,762 & 11,353 \\
\hline \multicolumn{8}{|l|}{ Memorandum Items } \\
\hline $\begin{array}{l}\text { Monetary base } \\
\text { Broad money (M4) } \\
\text { Credit to the private sector (National Currency) } \\
\text { Credit to the Private Sector (Foreign Currency) }\end{array}$ & $\begin{array}{l}26.9 \\
25.3 \\
34.0 \\
22.3\end{array}$ & $\begin{array}{l}33.0 \\
16.3 \\
45.2 \\
30.0\end{array}$ & $\begin{array}{l}11.9 \\
17.3 \\
27.1 \\
38.2\end{array}$ & $\begin{array}{r}7.1 \\
11.8 \\
9.7 \\
8.6\end{array}$ & $\begin{array}{r}7.7 \\
15.6 \\
3.4 \\
6.5\end{array}$ & $\begin{array}{r}8.5 \\
9.6 \\
10.8 \\
10.5\end{array}$ & $\begin{array}{l}10.0 \\
12.8 \\
12.4 \\
13.0\end{array}$ \\
\hline & \multicolumn{7}{|c|}{ (In percent of GDP) } \\
\hline Monetary base & 6.7 & 7.6 & 7.4 & 7.1 & 7.4 & 7.0 & 7.5 \\
\hline Broad money (M4) & 55.4 & 54.7 & 55.8 & 56.4 & 60.1 & 56.5 & 62.5 \\
\hline Credit to the private sector (National Currency) & 20.7 & 25.5 & 28.2 & 27.4 & 27.1 & 27.7 & 28.1 \\
\hline \multirow[t]{2}{*}{ Credit to the private sector (Foreign Currency) } & 17.0 & 18.8 & 22.6 & 22.0 & 22.4 & 22.2 & 23.3 \\
\hline & \multicolumn{7}{|c|}{ (In billion of Colones) } \\
\hline Net domestic assets (Program Definition) & -833 & $-1,009$ & -939 & $-1,016$ & $-1,098$ & $-1,115$ & $-1,123$ \\
\hline
\end{tabular}

Sources: BCCR; and Fund staff calculations. 
Table 8. External Financing Requirements and Sources 2006-10

(In millions of U.S. dollars)

\begin{tabular}{|c|c|c|c|c|c|c|c|}
\hline & \multirow[t]{2}{*}{2006} & \multirow[t]{2}{*}{2007} & \multirow[t]{2}{*}{2008} & \multicolumn{2}{|c|}{2009} & \multicolumn{2}{|c|}{2010} \\
\hline & & & & EBS/09/41 & Proj. & EBS/09/41 & Proj. \\
\hline 1. Gross Financing Requirements & 4,671 & 5,365 & 6,522 & 5,750 & 5,860 & 5,774 & 5,415 \\
\hline Current account deficit (exc. official transfers) & 1,151 & 1,647 & 2,728 & 1,602 & 1,057 & 1,656 & 1,474 \\
\hline Debt amortization 1/ & 2,486 & 2,879 & 4,108 & 4,148 & 4,803 & 4,018 & 3,841 \\
\hline Medium and long-term debt & 507 & 552 & 885 & 815 & 808 & 479 & 583 \\
\hline Public sector & 285 & 303 & 601 & 507 & 497 & 190 & 208 \\
\hline Corporate private sector & 222 & 248 & 284 & 308 & 311 & 289 & 375 \\
\hline Short-term debt 2/ & 1,979 & 2,327 & 3,224 & 3,333 & 3,995 & 3,539 & 3,258 \\
\hline Repayment of arrears & 0 & 0 & 0 & 0 & 0 & 0 & 0 \\
\hline Gross reserves accumulation & 1,034 & 839 & -315 & 0 & 0 & 100 & 100 \\
\hline 2. Available Financing & 4,671 & 5,365 & 6,522 & 5,750 & 5,860 & 5,774 & 5,415 \\
\hline Foreign direct investment (net) & 1,371 & 1,634 & 2,015 & 1,334 & 1,270 & 1,353 & 1,420 \\
\hline Debt financing & 2,880 & 3,929 & 5,174 & 4,594 & 4,159 & 4,482 & 4,363 \\
\hline Medium and long-term financing & 553 & 706 & 1,179 & 1,054 & 901 & 976 & 1,037 \\
\hline Public sector & 129 & 231 & 737 & 703 & 577 & 628 & 673 \\
\hline Private sector & 424 & 475 & 442 & 351 & 324 & 348 & 364 \\
\hline Short-term financing & 2,327 & 3,224 & 3,995 & 3,539 & 3,258 & 3,506 & 3,326 \\
\hline $\begin{array}{l}\text { Other flows } 3 / \\
\text { Memorandum Item: }\end{array}$ & 420 & -198 & -667 & -178 & 431 & -60 & -368 \\
\hline Gross financing requirement (in percent of GDP) & 20.7 & 20.4 & 22.0 & 19.1 & 20.0 & 18.6 & 17.8 \\
\hline
\end{tabular}

Sources: Authorities; and Fund staff estimates.

1/ Excluding the IMF.

2/ Original maturity of less than 1 year. Stock at the end of the previous period.

$3 /$ Includes all other net financial flows, and errors and omissions. 
Table 9. Costa Rica: Indicators of External Vulnerability 2006-10

\begin{tabular}{|c|c|c|c|c|c|}
\hline & \multirow[b]{2}{*}{2006} & \multirow[b]{2}{*}{2007} & \multirow[b]{2}{*}{2008} & \multicolumn{2}{|c|}{ Projection } \\
\hline & & & & 2009 & 2010 \\
\hline Merchandise exports (percent change) 1/ & 31.7 & 12.6 & 0.6 & -11.1 & 4.8 \\
\hline Merchandise imports (percent change) $1 /$ & 16.2 & 21.0 & 27.8 & -21.8 & 7.9 \\
\hline Terms of trade (percent change) & -3.9 & -3.7 & -4.6 & 5.2 & -2.3 \\
\hline Current account balance (in percent of GDP) & -5.1 & -6.3 & -9.2 & -3.6 & -4.8 \\
\hline Central bank net international reserves (in US\$ millions) & $3,114.6$ & $4,113.7$ & $3,799.1$ & $4,004.1$ & $4,104.1$ \\
\hline -In months of next year's imports of nonmaquila goods and services & 3.4 & 3.6 & 4.2 & 4.1 & 4.0 \\
\hline -In percent of base money & 208.6 & 199.3 & 183.3 & 190.1 & 182.3 \\
\hline -In percent of M4 & 25.3 & 27.6 & 24.2 & 23.4 & 21.9 \\
\hline -In percent of deposits in foreign currency & 68.0 & 85.3 & 62.6 & 56.6 & 51.9 \\
\hline -In percent of short-term external debt $2 /$ & 108.2 & 97.2 & 79.1 & 104.2 & 100.2 \\
\hline Public external debt service (in percent of GDP) & 2.0 & 1.8 & 3.1 & 2.3 & 1.3 \\
\hline External debt (in percent of GDP) & 31.0 & 31.8 & 31.0 & 31.3 & 30.3 \\
\hline External debt (in percent of exports) & 63.1 & 64.9 & 67.4 & 72.5 & 69.8 \\
\hline REER appreciation (+) & 0.9 & 2.8 & 5.4 & $\ldots$ & $\ldots$ \\
\hline
\end{tabular}

Sources: Central Bank of Costa Rica; and Fund staff estimates.

$1 /$ In value terms, excludes maquila.

2/ Public and private sector external debt on remaining maturity. Includes trade credits. 
Table 10. Costa Rica: Medium-Term Framework 2006-14

(Annual percentage change; unless otherwise indicated)

\begin{tabular}{|c|c|c|c|c|c|c|c|c|c|}
\hline & \multirow[b]{2}{*}{2006} & \multirow[b]{2}{*}{2007} & \multirow[b]{2}{*}{2008} & \multicolumn{6}{|c|}{ Projection } \\
\hline & & & & 2009 & 2010 & 2011 & 2012 & 2013 & 2014 \\
\hline Real GDP & 8.8 & 7.8 & 2.6 & -1.5 & 2.3 & 3.5 & 4.5 & 5.2 & 5.2 \\
\hline Consumption & 5.4 & 6.8 & 4.3 & 1.8 & 2.3 & 2.7 & 3.7 & 4.2 & 4.2 \\
\hline Private consumption & 5.7 & 7.4 & 4.5 & 1.6 & 2.1 & 2.7 & 3.8 & 4.4 & 4.4 \\
\hline Government consumption & 2.9 & 2.2 & 2.4 & 3.5 & 3.5 & 2.6 & 2.3 & 2.3 & 2.2 \\
\hline Gross domestic investment & 13.9 & -1.3 & 12.2 & -23.1 & 3.2 & 8.3 & 7.7 & 7.7 & 7.6 \\
\hline Fixed capital formation & 10.8 & 18.0 & 11.9 & -11.8 & 3.1 & 6.3 & 6.1 & 6.3 & 6.2 \\
\hline Exports of goods and nonfactor services & 10.3 & 10.0 & -1.8 & -6.0 & 2.7 & 3.6 & 5.5 & 6.5 & 6.4 \\
\hline Imports of goods and nonfactor services & 8.1 & 4.5 & 4.3 & -12.1 & 3.0 & 4.3 & 5.7 & 6.3 & 6.1 \\
\hline Consumption (contribution to growth) & 3.9 & 4.9 & 3.1 & 1.4 & 1.7 & 2.0 & 2.7 & 3.1 & 3.0 \\
\hline Investment (contribution to growth) & 2.2 & 3.7 & 2.7 & -2.9 & 0.7 & 1.4 & 1.4 & 1.5 & 1.5 \\
\hline Inventories (contribution to growth) & 1.4 & -4.0 & 0.2 & -3.2 & 0.0 & 0.3 & 0.3 & 0.3 & 0.3 \\
\hline Net exports (contribution to growth) & 1.3 & 3.2 & -3.4 & 3.2 & 0.0 & -0.2 & 0.1 & 0.4 & 0.4 \\
\hline \multicolumn{10}{|l|}{ Investment and savings (in percent of GDP) } \\
\hline Savings & 26.4 & 24.6 & 25.8 & 17.1 & 18.8 & 19.7 & 20.6 & 21.2 & 21.9 \\
\hline National savings & 21.3 & 18.3 & 16.6 & 13.5 & 13.9 & 14.9 & 15.7 & 16.5 & 17.1 \\
\hline External savings $1 /$ & 5.1 & 6.3 & 9.2 & 3.6 & 4.8 & 4.8 & 4.8 & 4.7 & 4.8 \\
\hline Gross domestic investment & 26.4 & 24.6 & 25.8 & 17.1 & 18.8 & 19.7 & 20.6 & 21.2 & 21.9 \\
\hline Private sector & 16.8 & 18.6 & 20.2 & 16.3 & 16.5 & 16.9 & 17.2 & 17.4 & 17.7 \\
\hline Public sector & 3.1 & 3.2 & 4.0 & 4.1 & 4.1 & 4.1 & 4.2 & 4.2 & 4.3 \\
\hline Inventory changes & 6.5 & 2.8 & 1.6 & -3.3 & -1.8 & -1.3 & -0.8 & -0.5 & -0.2 \\
\hline \multicolumn{10}{|l|}{ Balance of payments (in percent of GDP) } \\
\hline Current account balance & -5.1 & -6.3 & -9.2 & -3.6 & -4.8 & -4.8 & -4.8 & -4.7 & -4.8 \\
\hline Trade balance & -12.7 & -11.4 & -16.8 & -10.2 & -11.3 & -11.6 & -12.2 & -12.6 & -13.0 \\
\hline Services & 6.0 & 6.6 & 7.4 & 6.8 & 7.0 & 7.4 & 7.8 & 8.2 & 8.7 \\
\hline Income & 0.0 & -3.3 & -1.3 & -1.7 & -1.7 & -1.8 & -1.6 & -1.5 & -1.6 \\
\hline Current transfers & 1.6 & 1.8 & 1.5 & 1.4 & 1.2 & 1.2 & 1.1 & 1.1 & 1.1 \\
\hline Financial and capital account & 9.0 & 9.3 & 8.1 & 4.3 & 5.2 & 5.4 & 5.7 & 5.7 & 5.8 \\
\hline Direct investment & 6.1 & 6.2 & 6.8 & 4.3 & 4.7 & 4.7 & 4.7 & 4.7 & 4.7 \\
\hline Capital flows & 3.0 & 3.1 & 1.3 & 0.0 & 0.5 & 0.8 & 1.0 & 1.0 & 1.2 \\
\hline Public sector & -0.7 & -0.3 & 0.0 & 1.1 & 1.5 & 0.4 & 0.3 & 0.2 & 0.3 \\
\hline Private net capital & 3.7 & 3.4 & 1.3 & -1.1 & -1.0 & 0.4 & 0.8 & 0.8 & 0.9 \\
\hline Errors and Omissions & 0.7 & 0.7 & 0.0 & 0.0 & 0.0 & 0.0 & 0.0 & 0.0 & 0.0 \\
\hline Change in Net Reserves (increase -) & -4.6 & -3.8 & 1.1 & -0.7 & -0.3 & -0.6 & -0.9 & -1.0 & -1.0 \\
\hline \multicolumn{10}{|l|}{ Memorandum items: } \\
\hline GDP deflator & 11.0 & 9.3 & 12.1 & 8.9 & 6.0 & 5.2 & 4.4 & 4.2 & 4.0 \\
\hline CPI (avg) & 11.5 & 9.4 & 13.4 & 8.4 & 5.0 & 4.7 & 4.5 & 4.5 & 4.2 \\
\hline CPI (eop) & 9.4 & 10.8 & 13.9 & 5.0 & 5.0 & 4.5 & 4.5 & 4.5 & 4.0 \\
\hline Net international reserves (millions of US $\$$ ) & 3,115 & 4,114 & 3,799 & 4,004 & 4,104 & 4,304 & 4,604 & 4,954 & 5,354 \\
\hline
\end{tabular}

Sources: Central Bank of Costa Rica; and Fund staff estimates.

1/ External current account deficit. 
Table 11. Costa Rica: Banking Sector Indicators

(In percent)

\begin{tabular}{|c|c|c|c|c|c|c|c|c|c|}
\hline & \multicolumn{6}{|c|}{ Total Banking system } & \multirow{3}{*}{$\begin{array}{l}\text { Public } \\
\text { banks }\end{array}$} & \multirow{3}{*}{$\begin{array}{c}\begin{array}{c}\text { Private } \\
\text { Banks }\end{array} \\
2009 \\
\text { Jun }\end{array}$} & \multirow[t]{3}{*}{$\begin{array}{l}\text { Coope- } \\
\text { ratives }\end{array}$} \\
\hline & \multicolumn{4}{|c|}{2008} & \multicolumn{2}{|c|}{2009} & & & \\
\hline & Mar & Jun & Sep & Dec & Mar & Jun & & & \\
\hline \multicolumn{10}{|l|}{ Capitalization } \\
\hline Risk-adjusted capital ratio & 15.5 & 14.7 & 14.5 & 15.1 & 15.2 & 15.4 & 13.3 & 13.5 & 18.9 \\
\hline Capital-to-assets ratio & 12.8 & 12.8 & 12.8 & 13.3 & 13.3 & 13.5 & 11.8 & 10.4 & 18.5 \\
\hline \multicolumn{10}{|l|}{ Asset quality } \\
\hline Nonperforming loans to total loans & 1.2 & 1.1 & 1.2 & 1.5 & 1.8 & 2.0 & 2.6 & 1.5 & 1.0 \\
\hline Non-income generating assets to total assets & 16.6 & 17.0 & 18.1 & 18.2 & 19.1 & 18.9 & 21.0 & 19.3 & 5.6 \\
\hline Foreclosed assets to total assets & 0.2 & 0.2 & 0.2 & 0.3 & 0.4 & 0.4 & 0.4 & 0.5 & 0.3 \\
\hline Loan loss provisions to total loans & 1.8 & 1.7 & 1.7 & 1.8 & 1.9 & 1.9 & 2.1 & 1.6 & 2.9 \\
\hline \multicolumn{10}{|l|}{ Management } \\
\hline Administrative expenses to total assets & 4.8 & 4.6 & 4.5 & 4.4 & 4.3 & 4.3 & 4.7 & 3.7 & 4.3 \\
\hline Noninterest expenses to gross income & 77.2 & 79.6 & 82.2 & 79.3 & 78.9 & 77.4 & 78.1 & 84.4 & 38.1 \\
\hline Total expenses to total revenues & 90.6 & 91.0 & 91.7 & 92.5 & 93.0 & 93.5 & 93.2 & 95.8 & 88.6 \\
\hline \multicolumn{10}{|l|}{ Profitability } \\
\hline Return on assets (ROA) & 1.5 & 1.6 & 1.7 & 1.8 & 1.7 & 1.6 & 1.5 & 1.3 & 2.0 \\
\hline Return on equity (ROE) & 11.8 & 12.2 & 13.4 & 14.3 & 14.3 & 12.4 & 13.0 & 14.0 & 11.4 \\
\hline Interest margin to gross income & 34.0 & 29.4 & 25.6 & 20.8 & 20.4 & 20.8 & 24.4 & 12.7 & 37.7 \\
\hline \multicolumn{10}{|l|}{ Liquidity } \\
\hline Liquid assets to total short-term liabilities & 87.5 & 84.6 & 80.1 & 83.0 & 94.9 & 101.2 & 93.1 & 97.3 & 515.5 \\
\hline Liquid assets to total assets & 32.5 & 29.7 & 27.4 & 27.7 & 30.0 & 31.1 & 36.7 & 25.4 & 22.7 \\
\hline Loans to deposits & 103.1 & 107.3 & 109.8 & 109.7 & 101.9 & 98.6 & 78.6 & 121.9 & 157.2 \\
\hline Liquid assets to deposits & 48.5 & 44.6 & 41.0 & 42.1 & 43.7 & 44.8 & 47.8 & 38.6 & 48.0 \\
\hline Deposits as percent of M2 & 50.6 & 48.3 & 46.7 & 46.9 & 42.4 & 40.3 & 45.8 & 37.7 & 9.3 \\
\hline \multicolumn{10}{|l|}{ Sensitivity to market risk } \\
\hline Net open FX position to capital & 19.0 & 21.7 & 19.5 & 20.4 & 22.8 & 22.9 & 9.6 & 70.7 & 0.7 \\
\hline \multicolumn{10}{|l|}{ Other } \\
\hline Financial margin $1 /$ & 7.8 & 7.6 & 7.7 & 7.9 & 8.0 & 8.3 & 8.3 & 5.1 & 11.3 \\
\hline Credit growth (over a year ago) & 38.3 & 40.0 & 33.5 & 27.8 & 20.6 & 13.1 & 11.1 & 21.6 & 7.1 \\
\hline Deposit growth (over a year ago) & 22.4 & 23.8 & 21.3 & 25.4 & 21.9 & 23.1 & 16.7 & 41.3 & 17.0 \\
\hline
\end{tabular}

Source: Superintendency of Banks.

1/ Difference between implicit loan and deposit rates. 
Table 12. Country: External Debt Sustainability Framework, 2006-2014

(In percent of GDP, unless otherwise indicated)

\begin{tabular}{|c|c|c|c|c|c|c|c|c|c|c|c|c|}
\hline & \multirow[b]{2}{*}{2006} & \multirow[b]{2}{*}{2007} & \multirow[b]{2}{*}{2008} & & & \multicolumn{7}{|c|}{ Projection } \\
\hline & & & & & & 2009 & 2010 & 2011 & 2012 & 2013 & 2014 & \multirow{2}{*}{$\begin{array}{c}\text { Debt-stabilizing } \\
\text { non-interest } \\
\text { current account 6/ } \\
-3.4\end{array}$} \\
\hline Baseline: External debt & 31.0 & 31.8 & 31.0 & & & 31.3 & 30.3 & 29.4 & 28.6 & 27.6 & 27.1 & \\
\hline Change in external debt & -1.5 & 0.7 & -0.7 & & & 0.3 & -1.1 & -0.8 & -0.8 & -1.0 & -0.5 & \\
\hline Identified external debt-creating flows $(4+8+9)$ & -3.5 & -2.0 & 1.7 & & & 0.8 & -0.5 & -1.3 & -1.5 & -0.6 & -0.3 & \\
\hline Current account deficit, excluding interest payments & 3.9 & 4.6 & 8.0 & & & 2.2 & 3.6 & 3.2 & 3.0 & 2.9 & 3.1 & \\
\hline Deficit in balance of goods and services & -6.7 & -4.8 & -9.4 & & & -3.3 & -4.3 & -4.2 & -4.4 & -4.4 & -4.3 & \\
\hline Exports & 49.2 & 48.9 & 46.0 & & & 43.2 & 43.4 & 43.5 & 44.0 & 44.6 & 45.6 & \\
\hline Imports & -55.8 & -53.7 & -55.4 & & & -46.5 & -47.7 & -47.8 & -48.5 & -49.0 & -49.9 & \\
\hline Net nondebt creating capital inflows (negative) & -6.1 & -6.2 & -6.8 & & & -4.3 & -4.7 & -4.7 & -4.7 & -4.7 & -4.7 & \\
\hline Automatic debt dynamics $1 /$ & -1.4 & -0.4 & 0.4 & & & 2.9 & 0.6 & 0.2 & 0.2 & 1.1 & 1.3 & \\
\hline Contribution from nominal interest rate & 1.2 & 1.6 & 1.2 & & & 1.4 & 1.3 & 1.6 & 1.8 & 1.8 & 1.8 & \\
\hline Contribution from real GDP growth & -2.5 & -2.1 & -0.7 & & & 0.5 & -0.7 & -1.0 & -1.2 & -1.4 & -1.4 & \\
\hline Contribution from price and exchange rate changes $2 /$ & & & $\ldots$ & & & 1.0 & 0.0 & -0.4 & -0.4 & 0.7 & 0.9 & \\
\hline Residual, incl. change in gross foreign assets $(2-3) 3 /$ & 2.0 & 2.8 & -2.4 & & & -0.6 & -0.6 & 0.4 & 0.7 & -0.3 & -0.3 & \\
\hline External debt-to-exports ratio (in percent) & 63.1 & 64.9 & 67.4 & & & 72.5 & 69.8 & 67.6 & 65.0 & 62.0 & 59.5 & \\
\hline Gross external financing need (in billions of U.S. dollars) $4 /$ & 3,638 & 4,526 & 6,837 & & & 5,860 & 5,315 & 5,647 & 5,844 & 6,053 & 6,308 & \\
\hline in percent of GDP & 16.1 & 17.2 & 23.0 & $\begin{array}{l}\overline{10-Y e a r} \\
\text { Historical }\end{array}$ & $\begin{array}{l}\overline{10-Y e a r} \\
\text { Standard }\end{array}$ & 20.0 & 17.5 & 17.5 & 17.0 & 16.5 & 16.2 & \\
\hline Scenario with key variables at their historical averages 5 / & & & 31.0 & Average & Deviation & 31.0 & 30.2 & 30.3 & 30.4 & 30.6 & 30.8 & \\
\hline \multicolumn{13}{|l|}{ Key Macroeconomic Assumptions Underlying Baseline } \\
\hline Real GDP growth (in percent) & 8.8 & 7.8 & 2.6 & 5.0 & 2.8 & -1.5 & 2.3 & 3.5 & 4.5 & 5.2 & 5.2 & \\
\hline GDP deflator in U.S. dollars (change in percent) & 3.7 & 8.2 & 10.1 & 2.7 & 3.9 & 0.2 & 1.6 & 2.3 & 1.9 & 1.8 & 0.6 & \\
\hline Nominal external interest rate (in percent) & 4.1 & 6.1 & 4.2 & 6.5 & 3.3 & 4.3 & 4.3 & 5.6 & 6.6 & 6.6 & 6.6 & \\
\hline Growth of exports (U.S. dollar terms, in percent) & 13.9 & 16.1 & 6.2 & 7.6 & 10.4 & -7.3 & 4.2 & 6.4 & 7.7 & 8.4 & 8.1 & \\
\hline Growth of imports (U.S. dollar terms, in percent) & 16.8 & 12.1 & 16.5 & 9.1 & 7.5 & -17.0 & 6.5 & 6.1 & 8.0 & 8.2 & 7.8 & \\
\hline Current account balance, excluding interest payments & -3.9 & -4.6 & -8.0 & -3.7 & 1.7 & -2.2 & -3.6 & -3.2 & -3.0 & -2.9 & -3.1 & \\
\hline Net nondebt creating capital inflows & 6.1 & 6.2 & 6.8 & 4.4 & 1.5 & 4.3 & 4.7 & 4.7 & 4.7 & 4.7 & 4.7 & \\
\hline
\end{tabular}

$1 /$ Derived as $[r-g-\rho(1+g)+\varepsilon \alpha(1+r)](1+g+\rho+g \rho)$ times previous period debt stock, with $r=$ nominal effective interest rate on external debt; $\rho=$ change in domestic GDP deflator in U.S. dollar terms, $g=$ real GDP growth rate,

$\varepsilon=$ nominal appreciation (increase in dollar value of domestic currency), and $\alpha=$ share of domestic-currency denominated debt in total external debt.

$2 /$ The contribution from price and exchange rate changes is defined as $[-\rho(1+g)+\varepsilon \alpha(1+r)] /(1+g+\rho+g \rho)$ times previous period debt stock. $\rho$ increases with an appreciating domestic currency $(\varepsilon>0)$ and rising inflation (based on GDP deflator). $3 /$ For projection, line includes the impact of price and exchange rate changes.

4/ Defined as current account deficit, plus amortization on medium- and long-term debt, plus short-term debt at end of previous period.

dent inflows in percent of GDP.

6/ Long-run, constant balance that stabilizes the debt ratio assuming that key variables (real GDP growth, nominal interest rate, dollar deflator growth, and nondebt inflows in percent of GDP) remain at their levels of the last projection year. 
Table 13. Costa Rica: Combined Public Sector Debt Sustainability Framework, 2006-2014 (In percent of GDP, unless otherwise indicated)

\begin{tabular}{|c|c|c|c|c|c|c|c|c|c|c|c|c|}
\hline & & & & & \multicolumn{7}{|c|}{ Projections } & \multirow{3}{*}{$\begin{array}{c}\text { Debt- } \\
\text { Stabilizing } \\
\text { primary } \\
\text { balance 10/ }\end{array}$} \\
\hline & 2006 & 2007 & & & $2008^{-}$ & 2009 & 2010 & 2011 & 2012 & 2013 & $\overline{2014}$ & \\
\hline & & & & & & & & & & & & \\
\hline Baseline: Public sector debt $1 /$ & 47.8 & 43.2 & & & 35.8 & 39.9 & 41.6 & 41.0 & 39.6 & 37.4 & 35.2 & -0.2 \\
\hline Of which: foreign-currency denominated & 22.5 & 17.3 & & & 11.6 & 12.9 & 13.5 & 13.3 & 12.8 & 12.1 & 11.4 & \\
\hline Change in public sector debt & -4.9 & -4.5 & & & -7.4 & 4.0 & 1.8 & -0.6 & -1.4 & -2.3 & -2.2 & \\
\hline Identified debt-creating flows $(4+7+12)$ & -7.3 & -9.2 & & & -5.8 & 2.3 & 1.5 & -0.8 & -1.6 & -2.5 & -2.5 & \\
\hline Primary deficit (calculated using gross interest) $2 /$ & -4.5 & -5.3 & & & -3.2 & 1.5 & 1.3 & -0.6 & -1.2 & -1.9 & -2.0 & \\
\hline Revenue and grants & 32.8 & 33.6 & & & 35.9 & 32.2 & 34.2 & 35.2 & 35.9 & 36.4 & 36.5 & \\
\hline Primary (noninterest) expenditure & 28.2 & 28.3 & & & 32.7 & 33.7 & 35.5 & 34.6 & 34.7 & 34.5 & 34.4 & \\
\hline Automatic debt dynamics $3 /$ & -2.8 & -4.0 & & & -2.6 & 0.8 & 0.2 & -0.2 & -0.4 & -0.6 & -0.5 & \\
\hline Contribution from interest rate/growth differential 4/ & -3.8 & -3.2 & & & -2.6 & 0.8 & 0.2 & -0.2 & -0.4 & -0.6 & -0.5 & \\
\hline Of which contribution from real interest rate & 0.0 & 0.0 & & & -1.6 & 0.3 & 1.1 & 1.1 & 1.3 & 1.3 & 1.3 & \\
\hline Of which contribution from real GDP growth & -3.8 & -3.2 & & & -1.0 & 0.5 & -0.8 & -1.3 & -1.7 & -1.9 & -1.8 & \\
\hline Contribution from exchange rate depreciation $5 /$ & 1.1 & -0.8 & & & & $\ldots$ & & & & & & \\
\hline Other identified debt-creating flows & 0.0 & 0.0 & & & 0.0 & 0.0 & 0.0 & 0.0 & 0.0 & 0.0 & 0.0 & \\
\hline Privatization receipts (negative) & 0.0 & 0.0 & & & 0.0 & 0.0 & 0.0 & 0.0 & 0.0 & 0.0 & 0.0 & \\
\hline Recognition of implicit or contingent liabilities & 0.0 & 0.0 & & & 0.0 & 0.0 & 0.0 & 0.0 & 0.0 & 0.0 & 0.0 & \\
\hline Other (specify, e.g. bank recapitalization) & 0.0 & 0.0 & & & 0.0 & 0.0 & 0.0 & 0.0 & 0.0 & 0.0 & 0.0 & \\
\hline Residual, including asset changes $(2-3) 6 /$ & 2.4 & 4.7 & & & -1.6 & 1.7 & 0.2 & 0.2 & 0.2 & 0.2 & 0.3 & \\
\hline Public sector debt-to-revenue ratio $1 /$ & 145.8 & 128.9 & & & 99.8 & 123.7 & 121.7 & 116.5 & 110.5 & 102.7 & 96.6 & \\
\hline $\begin{array}{l}\text { Gross financing need } 7 / \\
\text { in billions of U.S. dollars }\end{array}$ & $\begin{array}{r}12.9 \\
2.9\end{array}$ & $\begin{array}{r}11.8 \\
3.1\end{array}$ & 10-Year & $10-$ Year & $\begin{array}{r}11.9 \\
3.5\end{array}$ & $\begin{array}{r}16.1 \\
4.7\end{array}$ & $\begin{array}{r}16.4 \\
5.0\end{array}$ & $\begin{array}{r}15.0 \\
4.8\end{array}$ & $\begin{array}{r}14.1 \\
4.8\end{array}$ & $\begin{array}{r}12.8 \\
4.7\end{array}$ & $\begin{array}{r}11.7 \\
4.6\end{array}$ & \\
\hline Scenario with key variables at their historical averages 8 / & & & & & 35.8 & 33.9 & 30.7 & 27.5 & 24.5 & 21.5 & 18.8 & -0.7 \\
\hline Scenario with no policy change (constant primary balance) in 2008-2013 & & & Historical & Standard & 35.8 & 35.2 & 32.3 & 29.1 & 25.7 & 22.3 & 19.0 & -0.1 \\
\hline Key Macroeconomic and Fiscal Assumptions Underlying Baseline & & & Average & Deviation & & & & & & & & \\
\hline Real GDP growth (in percent) & 8.8 & 7.8 & 5.6 & 2.9 & 2.6 & -1.5 & 2.3 & 3.5 & 4.5 & 5.2 & 5.2 & \\
\hline Average nominal interest rate on public debt (in percent) $9 /$ & 11.9 & 10.0 & 11.8 & 1.3 & 8.1 & 9.8 & 9.1 & 8.3 & 8.1 & 8.0 & 8.0 & \\
\hline Average real interest rate (nominal rate minus change in GDP deflator, in percer & 0.9 & 0.7 & 1.5 & 2.3 & -4.0 & 0.8 & 3.0 & 3.1 & 3.7 & 3.9 & 4.0 & \\
\hline Nominal appreciation (increase in U.S. dollar value of local currency, in percent) & -4.1 & 4.0 & -6.8 & 4.2 & -1.9 & $\ldots$ & $\ldots$ & $\ldots$ & $\ldots$ & $\ldots$ & $\ldots$ & \\
\hline Inflation rate (GDP deflator, in percent) & 11.0 & 9.3 & 10.3 & 2.3 & 12.1 & 8.9 & 6.0 & 5.2 & 4.4 & 4.2 & 4.0 & \\
\hline Growth in real primary spending of Combined Public Sector (in percent) & 8.1 & 9.9 & 6.2 & 3.8 & 14.8 & 15.3 & 6.6 & 2.2 & 4.5 & 4.8 & 5.0 & \\
\hline Primary deficit (calculated using net interest) & -2.8 & -4.1 & -2.1 & 1.1 & -2.3 & 2.4 & 2.3 & 0.0 & -0.5 & -1.3 & -1.5 & \\
\hline
\end{tabular}

1/ Public sector comprises central government, central bank, and the nonfinancial public sector (excluding ICE).

2/ For purposes of DSA, the primary deficit is the public sector balance minus gross interest expenditure, so does not coincide with the traditional measure (shown in the last line).

$3 /$ Derived as $[(r-\pi(1+g)-g+\alpha \varepsilon(1+r)] /(1+g+\pi+g \pi))$ times previous period debt ratio, with $r=$ interest rate; $\pi=$ growth rate of GDP deflator; $g=$ real GDP growth rate; $\alpha=$ share of foreign-currency

denominated debt; and $\varepsilon=$ nominal exchange rate depreciation (measured by increase in local currency value of U.S. dollar).

4/ The real interest rate contribution is derived from the denominator in footnote $2 /$ as $r-\pi(1+g)$ and the real growth contribution as $-\mathrm{g}$.

$5 /$ The exchange rate contribution is derived from the numerator in footnote $2 /$ as $\alpha \varepsilon(1+r)$

6/ For projections, this line includes exchange rate changes.

Defined as public sector deficit, plus amortization of medium and long-term public sector debt, plus short-term debt at end of previous period.

8 The key variables include real GDP growth; real interest rate; and primary balance in percent of GDP.

10/ Assumes that key variables (real GDP growth, real interest rate, and other identified debt-creating flows) remain at the level of the last projection year. 


\section{Attachment I. Letter of Intent}

San José, September 3, 2009

Mr. Dominique Strauss-Kahn

Managing Director

International Monetary Fund

Washington, D.C.

Dear Mr. Strauss-Kahn:

1. The purpose of this letter is to inform you about the progress in the implementation of our economic program, which is being supported under the Stand-by Arrangement (SBA) approved by the IMF Executive Board on April 10, 2009. The attached supplement to the Memorandum of Economic and Financial Policies (MEFP) summarizes developments since the inception of the SBA and describes modifications to the original program.

2. The global crisis has hit Costa Rica hard, but the economy continues to withstand the negative shock reasonably well. Economic growth during the first half of 2009 has been substantially weaker than anticipated, though there is some evidence that the real GDP decline is reaching an end. At the same time inflation has declined faster than expected, to a 30-year low of 5.7 percent $(y / y)$ in August. Lower growth and inflation have had a negative impact on fiscal revenues, which declined by more than 8 percent through June. Prudent execution of the budget, however, allowed the central government to post a somewhat smaller than projected deficit during the same period. The external current account deficit has narrowed substantially, and the overall balance of payments was in surplus during the first half of 2009. The banking system has remained sound, despite some pick up in nonperforming loans and a decline in bank profitability.

3. Performance against the program targets was very strong. All quantitative performance criteria for end-June were met, most with significant margins. We also have implemented all three end-June structural benchmarks (the unification of money markets suffered a slight delay owing to operational difficulties).

4. In light of this performance and our continued commitment to the program, we request completion of the first review under the SBA. Our intention remains to treat the arrangement as precautionary. Given the sharp decline in tax revenues, we request revisions of the endSeptember quantitative performance criteria on the overall cash balance and the debt stock of the central government. Program implementation will continue to be monitored through quarterly reviews. The revised quantitative performance criteria for end-September, new 
performance criteria for end-December 2009, indicative targets, and structural benchmarks under the program are set out in Tables 1 and 2 of the attached supplement to the MEFP.

5. We believe that the policies described in the attached supplement to the MEFP are adequate to meet the objectives of our program. However, if needed, the government stands ready to take additional measures. In accordance with the Fund's policies, we will be in continuous communication with the Fund with regard to policy actions related to this program.

Sincerely yours,

/s/

Jenny Phillips

Minister of Finance $\mid \mathrm{s} /$

Francisco de Paula Gutiérrez President, Central Bank of Costa Rica

Attachments 


\section{Attachment II. Supplement to the Memorandum of Economic and Financial Policies}

\section{September 3, 2009}

1. Recent Developments. During the first half of 2009, economic growth was substantially weaker than anticipated at the inception of the program. At the same time, vulnerabilities declined as the main domestic and external imbalances corrected in a relatively orderly way. Real GDP contracted by 4.8 percent (y/y) during the first quarter, driven by a sharp fall in inventories and reflecting mainly a decline in sectors dependent on external conditions (manufacturing, residential construction catering to foreigners, agriculture, and hotels). During the second quarter, the index of economic activity (IMAE) declined by 2.9 percent (y/y) but rose by 1.2 percent $(\mathrm{q} / \mathrm{q})$ on a seasonally adjusted basis, suggesting that the economy may have touched bottom. Reflecting the economic slowdown, improved terms of trade, and prudent monetary policy, inflation fell to the lowest level in several decades (5.7 percent (y/y) in August) and the external current account deficit in the first half of the year narrowed much more than expected (to 0.2 percent of GDP vs. 2.6 percent of GDP in the original program). Net capital inflows also declined, reflecting in part the repayment of credit lines by domestic banks and corporates, but were enough to cover the current account deficit and allow for an accumulation of net international reserves (NIR) of US\$137 million (compared to a US\$285 million decline allowed in the program). The banking system remained sound overall. While the nonperforming loan ratio rose and bank profitability declined, liquidity and solvency indicators remained adequate.

2. Performance under the program. All end-June quantitative performance criteria and structural benchmarks have been met.

- Quantitative performance criteria. Despite sharply lower tax revenues, the cash balance of the central government during the first six months of 2009 was C106 billion above the program floor, reflecting cautious spending execution.

- $\quad{ }^{1}$ Fiscal policy nonetheless provided strong support to domestic demand, as noninterest expenditures of the central government rose 14 percent in real terms. The debt stock of the central government as of end-June was below the program ceiling, albeit by a small margin as we took advantage of favorable conditions in the domestic market to prefinance part of our remaining borrowing requirement for the year. As noted, NIR exceeded the program floor, reflecting the larger than expected current account adjustment. With the stronger reserves position, net domestic assets of the central bank (BCCR) also remained well below the end-June ceiling.

\footnotetext{
${ }^{1}$ The indicative target for the cash balance of the combined public sector was also met with a margin.
} 
- $\quad$ Structural benchmarks. The daily exercise to forecast systemic liquidity and the preparation of monthly monitoring reports of the banking system were implemented significantly ahead of the end-June target date. The unification of the money market was slightly delayed, but the integrated platform for liquidity operations (MIL) finally became operational in early August and the BCCR now only conducts liquidity injections through this market.

3. Revised macroeconomic framework. We have adjusted the macroeconomic framework to take into account the outcome of the first half of 2009 and the revised forecasts for commodity prices and global growth. Overall, the outlook for Costa Rica's economy remains for a gradual recovery, in line with the turnaround expected for our trading partner countries.

- Real GDP in 2009 is now expected to decline by 1-1.5 percent (compared to the 0.5 percent growth envisaged at program approval). This forecast takes into account the recent signs of a stabilization in output and a more positive outlook for manufacturing exports in the second half of the year. Real GDP growth for 2010 has been revised upward (to 2.25-2.75 percent), reflecting the improved outlook for growth in the United States and other trading partners.

- $\quad$ End-year inflation is now projected to be around 5 percent in 2009 (8 percent in the original program). The program's inflation goal for 2010 has been revised to 5 percent, in line with the mid-point of the BCCR's target range.

- $\quad$ The external current account deficit for 2009 is now projected at 3.6 percent of GDP (down from 5.3 percent of GDP at program approval). The balance of payments is expected to remain in overall balance (excluding the inflows from the special and general SDR allocations), as the net repayment of external credit lines by banks and lower disbursements of official loans are projected to reduce the capital account surplus by broadly the same amount as the decline in the current account deficit. In 2010, the external current account deficit would widen to 4.8 percent of GDP, as international oil prices are expected to increase and non-oil import growth bounces back with the recovery.

4. Fiscal policy. The lower than projected growth and inflation will compromise the achievement of our original revenue targets. For 2009 as a whole, we anticipate a revenue shortfall of C290 billion from the original program projection of C2,722 billion. Part of the lower revenue will be passed on to the deficit of 2009. This will allow us to protect social spending and provide sufficient support to domestic demand, while keeping the increases in the domestic borrowing requirement and the debt-to-GDP ratio within reasonable margins. Overall, the revised program will target a central government deficit of C680 billion or 4.1 percent of GDP in 2009. The revised deficit of the combined public sector will increase by slightly less than the deficit of the central government, and remain well under 5 percent of GDP. To finance the additional deficit, we will increase our domestic borrowing and, if necessary, resort to the central government's accumulated cash reserves (1.2 percent of GDP as of late August 2009). For 2010, 
we will target a central government deficit of 4.1 percent of GDP (C140 billion higher than in the original program), and a combined public sector deficit of 4.7 percent of GDP. To avoid crowding out private sector credit, we will seek to finance a substantial share of next year's fiscal deficit with resources from abroad, including by drawing on the $\$ 500$ million contingent credit line from the World Bank that is currently awaiting approval in the Legislative Assembly.

5. Monetary and external sector policies. The stronger external position and the sharp deceleration of inflation have created some room for monetary easing. Correspondingly, the BCCR reduced in mid-July the policy interest rate from 10 percent to 9 percent and the overnight deposit rate from 7.75 percent to 7.25 percent. In the period ahead, we will continue to monitor closely domestic liquidity conditions and the attractiveness of the colon to gauge the appropriateness of our interest rate level. We remain committed to adjusting interest rates as necessary to achieve the end-2010 inflation target and maintain orderly conditions in the foreign exchange market. To further bolster our international reserves position, we intend to save the additional SDR allocation of the IMF (about US\$205 million).

6. Financial sector policies. Despite the resilience that the banking system has displayed so far, we will remain vigilant and continue the intensive monitoring of the banking sector. We remain committed to working closely with our Legislative Assembly to obtain approval of the draft laws to establish consolidated supervision of financial conglomerates and recapitalize the BCCR. We will also continue to address remaining gaps in the financial sector safety net, including through the submission to the Legislative Assembly of draft laws to establish a bank resolution framework in line with international best practice and create a deposit insurance scheme (both now benchmarks for end-December 2009).

7. Safeguards assessment. A safeguards assessment of the BCCR was completed in July 2009. The assessment found that the bank has a sound operating control environment, in particular covering the management of official reserves and internal audit functions, and made a number of recommendations to further strengthen the BCCR's safeguards framework. Key recommendations include the appointment of an external auditor to conduct annual audits of the BCCR financial statements from 2008 onwards, the implementation of International Financial Reporting Standards (IFRS) by 2011, and the establishment of Audit Committee functions. We are committed to implementing the assessment's recommendations; in particular, the BCCR has already initiated the process to select an external auditor and will include in the services to be contracted an analysis of the existing gaps between the BCCR's accounting practices and IFRS, in order to establish an action plan for the implementation of IFRS.

8. Program monitoring. The program will continue to be monitored on a quarterly basis, by quantitative performance criteria, indicative targets, and structural benchmarks. The phasing of access under the arrangement and the structural benchmarks of the program remain unchanged (Tables 1 and 2). The quantitative performance criteria and indicative targets for endSeptember 2009 and end-December 2009 are set out in Table 3 (quantitative performance criteria for March 2010 will be defined at the time of the second program review). 
Table 1. Costa Rica: Quantitative Performance Measures

2009 Program

(In billion of colones, unless otherwise indicated)

\begin{tabular}{|c|c|c|c|}
\hline End-March /1 & End-June & End-September & End-December \\
\hline EBS/09/41 Actual & $\begin{array}{ll}\text { EBS/09/41 Actual } \\
\end{array}$ & $\overline{\text { EBS/09/41 Proposed }}$ & EBS/09/41 Proposed \\
\hline
\end{tabular}

\section{Quantitative Performance Criteria}

Floor on cash balance of the Central Government (cumulative)

Ceiling on the debt stock of the Central Government

Ceiling on NDA of the Central Bank 2/

Floor on NIR of the Central Bank (million of US\$) /2

Continuous Performance Criteria

Accumulation of external debt arrears

\section{Indicative targets}

Floor on cash balance of the combined public sector (cumulative)

A

\begin{tabular}{rrrrrrrr}
-210 & -106 & -312 & -206 & -403 & -471 & -492 & -639 \\
4,303 & 4,239 & 4,356 & 4,338 & 4,447 & 4,753 & 4,535 & 4,871 \\
-915 & $-1,301$ & -786 & $-1,244$ & -814 & -970 & -784 & -896 \\
3,500 & 4,167 & 3,350 & 3,936 & 3,350 & 3,555 & 3,500 & 3,705 \\
& & & & & & & \\
0 & 0 & 0 & 0 & 0 & 0 & 0 & 0 \\
-146 & -43 & -325 & -179 & -402 & -524 & -672 & -774 \\
1,102 & 1,101 & 1,144 & 1,024 & 1,116 & 1,079 & 1,233 & 1,240 \\
576 & 558 & 576 & 569 & 576 & 576 & 576 & 576 \\
\hline
\end{tabular}

Memorandum item

Base money

Program exchange rate (ask price)

576

1/ Projection only. Performance criteria were only set from end-June onward.

2/ The floor on NIR and ceiling on NDA at end-September and end-December have been adjusted by $\$ 205$ million compared to the levels set at program approval (IMF Country Report No. 09/134) to reflect the special and general SDRs allocations of 132.81 millions SDRs. 
Table 2. Structural Benchmarks

\begin{tabular}{lll}
\hline & Test Date & Status \\
\hline $\begin{array}{l}\text { Establishment of a monthly monitoring report for } \\
\text { the banking system }\end{array}$ & End-June 2009 & Met \\
$\begin{array}{l}\text { Unification of the money market under a single } \\
\text { platform }\end{array}$ & End-June 2009 & Met (by August 2009) \\
$\begin{array}{l}\text { Establishment of a system of daily forecasting of } \\
\text { systemic liquidity in the money market }\end{array}$ & End-June 2009 & Met \\
$\begin{array}{l}\text { Submission to parliament of a draft law to } \\
\text { strengthen the bank resolution framework. }\end{array}$ & End-December 2009 & \\
$\begin{array}{l}\text { Submission to parliament of a draft law to create a } \\
\text { limited deposit guarantee scheme. }\end{array}$ & End-December 2009 \\
\hline
\end{tabular}

Table 3. Schedule of Availability of Disbursements

\begin{tabular}{lll}
\hline Amount & Date & Conditions for Disbursement \\
\hline SDR 328,200,000 & $\begin{array}{l}\text { April 10, } \\
2009\end{array}$ & $\begin{array}{l}\text { Executive Board approval of the 18-month Stand-by } \\
\text { Arrangement }\end{array}$ \\
SDR 41,025,000 & $\begin{array}{l}\text { September 23, } \\
2009\end{array}$ & $\begin{array}{l}\text { Observance of performance criteria for end-June 2009 and } \\
\text { completion of the first review under the Stand-by Arrangement }\end{array}$ \\
SDR 41,025,000 & $\begin{array}{l}\text { December 14, } \\
2009\end{array}$ & $\begin{array}{l}\text { Observance of performance criteria for } \\
\text { end-September 2009 and completion of the second review } \\
\text { under Stand-by Arrangement }\end{array}$ \\
SDR 41,025,000 & $\begin{array}{l}\text { March 16, } \\
2010\end{array}$ & $\begin{array}{l}\text { Observance of performance criteria for } \\
\text { end-December 2009 and completion of the third review under } \\
\text { the Stand-by Arrangement }\end{array}$ \\
SDR 41,025,000 & June 17, & $\begin{array}{l}\text { Observance of performance criteria for end-March } 2010 \text { and } \\
\text { completion of the fourth review under the Stand-by } \\
\text { Arrangement }\end{array}$ \\
\hline
\end{tabular}




\section{Attachment III. Technical Memorandum of Understanding}

This Technical Memorandum of Understanding (TMU) sets out the understandings between the government of Costa Rica and IMF staff regarding the definitions of quantitative and structural performance criteria and reporting requirements under the Precautionary Stand-By Arrangement (SBA).

\section{Definitions}

\section{Program Exchange Rates}

For the purposes of the program (and not as a target rate), the average exchange rate is set at 576.3 Costa Rican colones per U.S. dollar. The exchange rates against the SDR and Euro are provided in Table 1. The program rate for the inflation indexed unit (UDES) is set at 683.4 colones.

Table 1. Program Exchange Rates in 2009

\begin{tabular}{ll}
\hline U.S. dollar & 576.3 \\
SDR & 886.1 \\
Euro & 792.0 \\
UDES & 683.4 \\
\hline
\end{tabular}

\section{Central Government}

Numbers referring to the central government include the central government budget and extra budgetary funds. If the government establishes new extra budgetary funds, they will be consolidated within the central government system.

\section{Combined Public Sector}

For program purposes, the combined public sector includes the central government, the central bank, public enterprises (excluding the Instituto Costarricense de Electricidad (ICE)) and a number of decentralized institutions (Table 2). 
Table 2. List of Public Agencies in the Combined Public Sector

\author{
Public Enterprises \\ Consejo Nacional de Produccion \\ Instituto Costarricense de Acueductos y Alcantarillados \\ Instituto Costarricense de Puertos del Pacifico \\ Junta de Proteccion Social \\ Refinadora Costarricense de Petróleo \\ Decentralized Agencies \\ Caja Costarricense de Seguro Social \\ Consejo Tecnico de Asistencia Medico Social \\ Fondo de Desarrollo Social y Asignaciones Familiares \\ Instituto Costarricense de Turismo \\ Instituto de Desarrollo Agrario \\ Instituto Nacional de Apredizaje \\ Oficina de Cooperacion International de la Salud
}

\title{
Quantitative Performance Criteria, Indicative Targets, and Continuous Performance Criteria: Definitions and Reporting Standards
}

\section{A. Floor on the Cash Balance of the Central Government}

The cash balance is defined as the difference between total revenues and expenditures. The floor on the cash balance of the central government will be monitored from above the line on a cash basis. The interest component of expenditures excludes the capitalized inflation component of inflation-indexed zero coupon bonds (TUDES).

\section{B. Floor on the Cash Balance of the Combined Public Sector}

The cash balance is defined as the difference between total revenues and expenditures. The floor on the cash balance of the combined public sector will be monitored from above the line on a cash basis. The balance of the central bank will be measured on an accrual basis. The interest component of expenditures excludes the capitalized inflation component of inflationindexed zero coupon bonds (TUDES) held outside of the combined public sector. 


\section{Floor on Net International Reserves of the Central Bank of Costa Rica}

Net international reserves (NIR) of the central bank of Costa Rica (BCCR) are defined as the U.S. dollar value of gross foreign assets minus gross foreign liabilities of the BCCR.

- Gross foreign assets are defined in conformity with the Special Data Dissemination Standard as readily available claims on nonresidents denominated in foreign convertible currencies. They include the BCCR's holdings of monetary gold, SDRs, foreign currency cash, foreign currency securities, deposits abroad, and the country's reserve position at the Fund. Excluded from reserve assets are any assets that are pledged, collateralized, or otherwise encumbered, claims on residents, claims in foreign exchange arising from derivatives in foreign currencies vis-à-vis domestic currency (such as futures, forwards, swaps, and options), precious metals other than gold, assets in nonconvertible currencies, and illiquid assets.

- Gross foreign liabilities are defined as all short-term foreign exchange liabilities to nonresidents, including commitments to sell foreign exchange arising from derivatives (such as futures, forwards, swaps, and options) and all credit outstanding from the Fund.

\section{Ceiling on Net Domestic Assets of the Central Bank of Costa Rica}

Net domestic assets of the BCCR are defined as the difference between base money and the NIR of the BCCR converted at program exchange rates, where base money is defined as the sum of currency issued and domestic currency reserve deposits of deposit-taking financial intermediaries at the central bank. 


\section{E. Ceiling on the Debt Stock of the Central Government}

The ceiling on the stock of central government debt shall apply to all debt defined as set forth in point no. 9 of the Guidelines on Performance Criteria with Respect to Foreign Debt (Decision No. 12274-00/85) ${ }^{1}$ Excluded from this performance criterion are normal short-term import credits. All foreign currency denominated debt will be converted into colones using the program exchange rates set out in Table 1. All domestic debt denominated in inflation indexed units (TUDES) will be converted into colones using the program rate set out in Table 1.

\section{F. Continuous Performance Criteria on Nonaccumulation of External Arrears}

The central government will accumulate no external debt arrears during the program period. For the purposes of this performance criterion, an external debt payment arrear will be defined as a payment by the central government system which has not been made within seven days after falling due under the contractual agreement, unless specified otherwise. The performance criterion will apply on a continuous basis.

\section{G. Adjustors}

The floor on the NIR will be adjusted upward and the ceiling on NDA downward by the amount of external financing contracted by the central bank, excluding funding used to provide liquidity support to the financial sector and IMF disbursements.

\footnotetext{
${ }^{1}$ The definition of debt set forth in point No. 9 of the IMF's guidelines reads as follows: "(a) For the purpose of this guideline, the term "debt" will be understood to mean a current, i.e., not contingent, liability, created under a contractual arrangement through the provision of value in the form of assets (including currency) or services, and which requires the obligor to make one or more payments in the form of assets (including currency) or services, at some future point(s) in time; these payments will discharge the principal and/or interest liabilities incurred under the contract. Debts can take a number of forms, the primary ones being as follows: (i) loans, i.e., advances of money to obligor by the lender made on the basis of an undertaking that the obligor will repay the funds in the future (including deposits, bonds, debentures, commercial loans and buyers' credits) and temporary exchanges of assets that are equivalent to fully collateralized loans under which the obligor is required to repay the funds, and usually pay interest, by repurchasing the collateral from the buyer in the future (such as repurchase agreements and official swap arrangements); (ii) suppliers' credits, i.e., contracts where the supplier permits the obligor to defer payments until some time after the date on which the goods are delivered or services are provided; and (iii) leases, i.e., arrangements under which property is provided which the lessee has the right to use for one or more specified period(s) of time that are usually shorter than the total expected service life of the property, while the leaser retains the title to the property. For the purpose of the Guideline, the debt is the present value (at the inception of the lease) of all lease payments expected to be made during the period of the agreement excluding those payments that cover the operation, repair, or maintenance of the property. (b) Under the definition of debt set out in point 9(a) above, arrears, penalties, and judicially awarded damages arising from the failure to make payment under a contractual obligation that constitutes debt are debt. Failure to make payment on an obligation that is not considered debt under this definition (e.g., payment on delivery) will not give rise to debt."
} 


\section{Clarification of Structural Conditions}

Benchmark for end-June 2009 on the establishment of a monthly monitoring report for the banking system: Preparation of a monthly report to monitor the liquidity position of the banking system on a bank-by-bank basis.

Benchmark for end-June 2009 on establishing a system of daily forecasting of systemic liquidity in the money market: Establish a daily liquidity forecasting exercise, containing a comprehensive assessment of liquidity supply and demand based on the compilation and consolidation of information on liquidity needs, a forecasting methodology, close communication with market participants and relevant parties, real-time monitoring of money market transactions, and an assessment of the size and scope of BCCR's market intervention and its effectiveness.

Benchmark for end-June 2009 on unification of the money market under a single platform: Establishment of an integrated liquidity market (MIL) that will include the following: (i) the introduction of a short-term lending facility that sets an interest rate ceiling to guide the market rate; (ii) the BCCR's withdrawal from the interbank money market (MIB); and (iii) disallowing access for financial entities to the central bank's deposit facility (Central Director) for maturities of 30 days or less, except for deposits with maturities that mirror the maturities offered by the MIL lending facility.

Benchmark for end-December 2009 on submission to parliament of a draft law to strengthen the bank resolution framework: The draft law should provide for a more robust bank resolution framework. This framework should allow for the orderly transfer of assets and liabilities of an insolvent bank to another institution, while imposing first losses on shareholders and subordinated creditors before any of the general creditors, the deposit insurance scheme, or the government incur costs.

Benchmark for end-December 2009 on submission to parliament of a draft law to create a limited deposit insurance scheme: The draft law should establish a deposit insurance scheme, which includes the following elements: contain a clear ex ante funding mechanism, provide for rules to allow for the swift compensation of depositors in the event of a bank failure, and describe the linkages to the bank resolution framework. 


\section{Program Reporting Requirements}

The following information will be provided to the Western Hemisphere Department of the IMF within the time frame indicated.

- Data on the cash balance of the central government will be provided within 6 weeks of the end of the month to which the cash balance is calculated.

- $\quad$ Data on the cash balance of the nonfinancial public sector will be provided within 8 weeks of the end of the month to which the cash balance is calculated.

- $\quad$ NIR will be provided on a daily basis

- $\quad$ NDA will be provided on a daily basis.

- Data on the total stock of debt of the central government system will be provided on a quarterly basis within one month of the end of each quarter. 


\section{INTERNATIONAL MONETARY FUND}

\section{COSTA RICA}

\section{Article IV Consultation and First Review Under the Stand-By Arrangement-Informational Annex}

Prepared by the Western Hemisphere Department

(In consultation with other departments)

September 9, 2009

I. Relations with the Fund

II. Relations with the World Bank Group.

III. Relations with the Inter-American Development Bank.

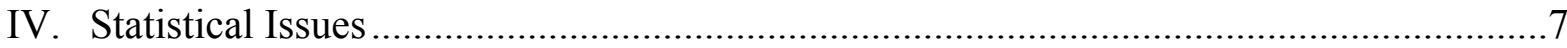


I. Relations with the Fund

9. Membership Status. Costa Rica joined the IMF on January 8, 1946.

10. Exchange Rate Arrangements. Costa Rica's current exchange arrangement is a crawling currency band that was introduced in October 2006. The ceiling and floor of the band have been adjusted several times, most recently in January 2009 when the slope of the ceiling of the band was raised to 9 percent per year. Costa Rica has accepted the obligations of Article VIII, Sections 2, 3, and 4 of the Articles of Agreement and maintains an exchange system that is free of restrictions on the making of payments and transfers for current international transactions. Buying and selling exchange rates were 587 colones per U.S. dollar and 588 colones per U.S. dollar, respectively, as of August 26, 2009.

11. Last Article IV Consultation. Concluded on February 15, 2008 (SM/08/40). The next Article IV consultation will take place in accordance with the July 15, 2002 decision on consultation cycles.

12. FSAP Participation and ROSCs Assessments. FSAP took place in October and December 2001, and was updated in October 2007. A data ROSC took place in July 2001, and a reassessment in April 2009. A fiscal ROSC took place in April 2006.

13. Recent Technical Assistance. Costa Rica has benefited from IMF technical assistance in the areas of macroeconomic statistics, monetary and exchange rate management, banking sector supervision, and fiscal issues. Recent technical assistance missions included:

\begin{tabular}{|l|l|l|}
\hline Department & \multicolumn{1}{|c|}{ Dates } & \multicolumn{1}{c|}{ Purpose } \\
\hline STA & February 2008 & Monetary and financial statistics \\
& November 2007 & Government Finance Statistics \\
September 2006 & Balance of payments and IIP statistics. \\
& May 2006 & Consumer prices/Producer prices \\
MCM & $\begin{array}{l}\text { December 2008 } \\
\text { November 2008 }\end{array}$ & Reorganization of SUGEF and Modernization of Supervisory Practices \\
& Reorganization of SUGEF and Modernization of Supervisory Practices \\
& September 2008 & Supervision of Foreign Exchange Risk and Foreign Exchange Operations \\
& August 2008 & Central Bank FX Intervention \\
& October 2007 & Reorganization of SUGEF and Modernization of Supervisory Practices \\
& July 2007 & Bnking Supervision and Regulation \\
& August 2006 & Bank Supervision \\
& August 2006 & Effective supervision under partial dollarization. \\
& March 2006 & Operational aspects of monetary and exchange rate policies \\
& February 2006 & Financial system supervision \\
& April 2009 & Safeguards Assessment of the Banco Central de Costa Rica \\
& FIN &
\end{tabular}


14. Financial position in the Fund. Costa Rica's financial position in the Fund as of July 31, 2009 was as follows:

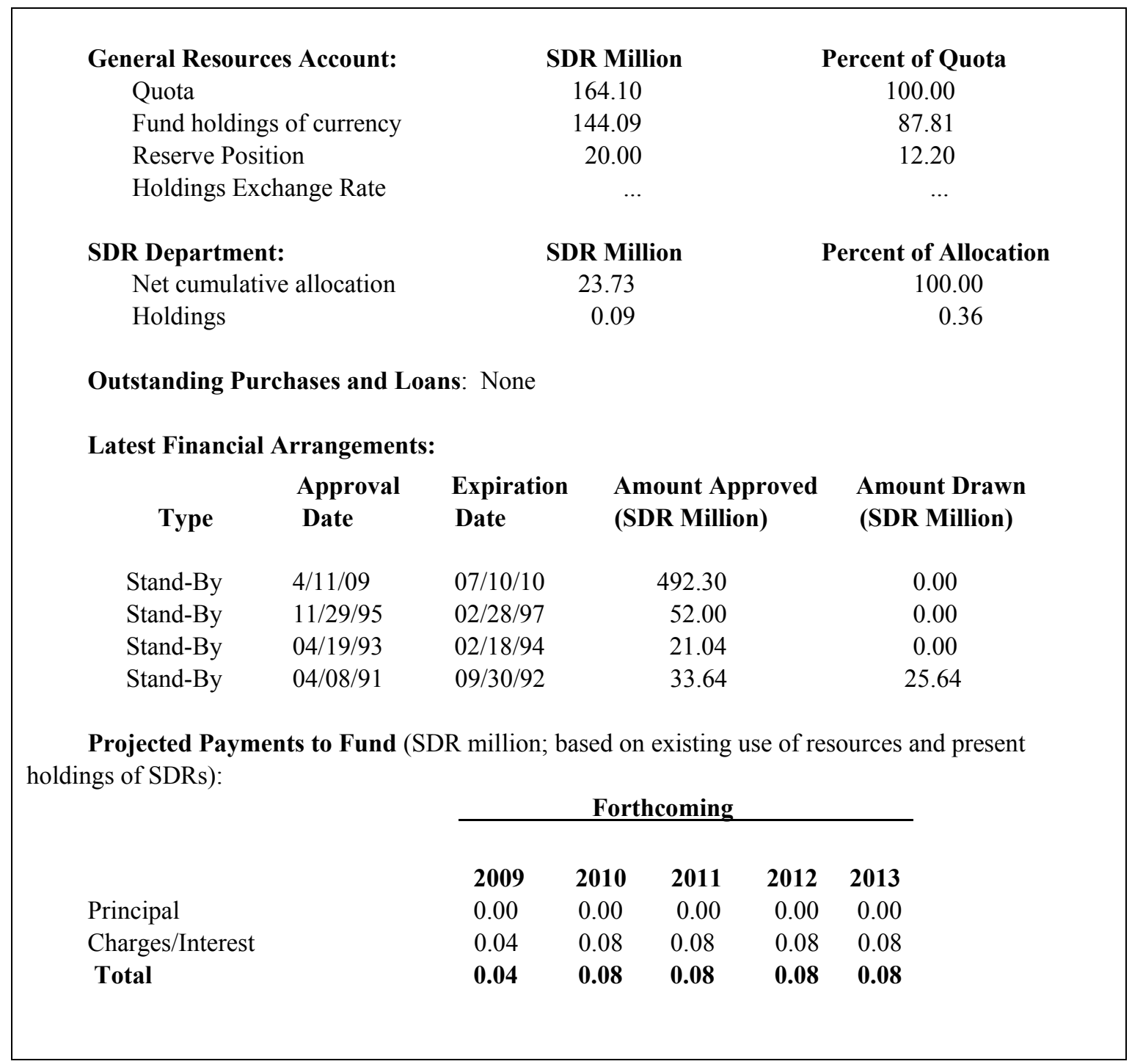


II. Relations with the World Bank Group

15. The Country Partnership Strategy (CPS) covers the remaining term of the current administration and an additional seven months following the presidential transition in May 2010. It includes a selective, demand-driven program of lending based on the government's policy priorities. The CPS supports the Government's objective of developing a comprehensive risk management framework in the context of an increasingly unfavorable external environment. The program consists of four lending operations, totaling US\$258 million, targeted to specific areas: a Disaster Risk Management Development Policy Loan with a Catastrophe Deferred Drawdown Option (CAT DDO) of \$65m; a Secondary Education Quality and Competitiveness Project $(\$ 80 \mathrm{~m})$; a Telecommunications TA $(\$ 13 \mathrm{~m})$; and an Integrated Infrastructure Development of the City-Port of Puntarenas ( $\$ 100 \mathrm{~m})$. The program also includes a reimbursable TA operation for the social security agency (CCSS) in the management of pension assets and supporting continued strengthening of the health system; and, a nonreimbursable TA operation related to competitiveness, poverty targeting, and social assistance.

16. Although not specifically included in the 2008-2010 CPS, in April 30, 2009 the World Bank's Board approved a US\$500 million contingent line of credit to boost the country's competitiveness, strengthen its public finances and respond to the global financial crisis. The Development Policy Loan with a Deferred Drawdown Option (DPLDDO) supports the Government's efforts aimed at: (i) strengthening public finances and their transparency by enhancing the efficiency of revenue generation and results-based management of expenditures; (ii) improving competitiveness by enhancing secondary education, and expanding the beneficiaries of the conditional cash transfer program; and (iii) establishing operational regulatory authorities for the telecommunications and insurance sectors, and reinforcing the legal framework pertaining to intellectual property rights.

17. The loan will be disbursed in a single tranche of US\$500 million, payable in 30 years, including five years of grace period, following the National Assembly's approval. Although it is a single tranche operation, the actions being supported by the DPLDDO have formed part of a longer-standing policy dialogue that has been carried out through various ongoing operations and, particularly, in the context of the Bank's Analytical and Advisory Activities (AAA) support, such as the Costa Rica Public Expenditure Review (March 2008) and the Competitiveness Diagnostic and Recommendations (July 2009). Consultation with the IMF was particularly close in the context of carrying out the Debt Sustainability Analysis and in the assessment of macroeconomic and financial risks. The prior actions in this DPL-DDO complement the actions in the IMF program. The DPL-DDO harmonizes and complements Bank operations in agriculture, disaster risk management, health and nutrition, education, and infrastructure. Details on the outstanding portfolio are in the table below. 


\section{Costa Rica: Financial Relations with the World Bank Group}

(in millions of U.S. dollars as of August 26, 2009)

\begin{tabular}{|c|c|c|c|c|c|c|}
\hline Active IBRD Lending Operations by Sector & & \multicolumn{2}{|r|}{ Committed } & \multicolumn{2}{|c|}{ Disbursed } & Undisbursed \\
\hline TOTAL & & & $\underline{711.5}$ & \multicolumn{2}{|c|}{$\underline{27.0}$} & $\underline{684.5}$ \\
\hline Agriculture & & & 30.0 & \multicolumn{2}{|c|}{3.0} & 27.0 \\
\hline CAT DDO & & & 65.0 & \multicolumn{2}{|c|}{12.0} & 53.0 \\
\hline Health, Population, and Nutrition & & & 14.0 & \multicolumn{2}{|c|}{9.5} & 4.5 \\
\hline Education & & & 30.0 & \multicolumn{2}{|c|}{2.5} & 27.5 \\
\hline Public Finance and Competitiveness - DDO & & & 500.0 & \multicolumn{2}{|c|}{0.0} & 500.0 \\
\hline City-Port Integrated Infrastructure & & & 72.5 & \multicolumn{2}{|c|}{0.0} & 72.5 \\
\hline IBRD Disbursements by Fiscal Year & 2004 & 2005 & 2006 & 2007 & 2008 & 2009 \\
\hline Gross Disbursements & 7.3 & 7.0 & 5.9 & 2.5 & 2.9 & 4.1 \\
\hline Principal Repayments (-) & 17.2 & 16.8 & 14 & 11.2 & 7.7 & 8.0 \\
\hline Total Net Disbursements & -9.9 & -9.8 & -8.1 & -8.7 & -4.8 & -3.9 \\
\hline Interests and Fees (-) & 4.9 & 3.1 & 2.7 & 3.3 & 2.9 & 2.4 \\
\hline Total net Cash Flows & -14.8 & -12.9 & -10.8 & -11.9 & -7.7 & -6.3 \\
\hline
\end{tabular}

III. Relations with the Inter-American Development Bank

18. Recent activities. Congressional ratification and declaration of eligibility of IDB approved projects resumed in 2008 after a period of four years. The IDB still has four operations awaiting legislative ratification, including a program for supporting competitiveness, two infrastructure loans and the tourism program for protected areas. The Liquidity Program for Growth Sustainability, a US\$500 million dollar loan for the financial sector approved by the IDB in December 2008, was cancelled by the Costa Rican authorities on June 12, 2009 because of the improvement in the conditions on international markets. Disbursements for the Electric Power Sector Development Program are expected to begin in the last quarter of 2009. A Water and Sanitation Investment Program is currently under preparation and expected to be approved by the end of 2009 .

19. Future plans. The IDB is currently preparing for the policy dialogue with the next government, to take place in 2010 after the elections. The IDB intends to be involved in operations in the infrastructure (electric, roads, and transport) and social sectors. 


\section{Operations (as of August 28, 2009)}

(In millions of U.S. dollars)

\begin{tabular}{lrrrr}
\hline & Approved & Disbursed & Obligated & Available \\
\hline Loans in execution & $\mathbf{8 8 6 . 9}$ & $\mathbf{6 9 . 7}$ & $\mathbf{1 0 . 3}$ & $\mathbf{8 0 6 . 8}$ \\
Cadaster and Register Regularization & 65.0 & 25.6 & 0.0 & 39.4 \\
Central American Electric Interconnection & 30.0 & 19.9 & 9.0 & 1.2 \\
Judiciary Modernization Program & & 17.8 & 0.0 & 4.6 \\
Sustainable Development of Food and Agriculture & 22.4 & & & \\
Sector & 14.4 & 6.1 & 1.3 & 6.9 \\
Sustainable Development of the Binational & & & & \\
watershed Rio Sixaola & 9.2 & 0.3 & 0.0 & 8.9 \\
Competitiveness Investment Program & 116.8 & 0.0 & 0.0 & 116.8 \\
Tourism Program in Protected Areas & 19.00 & 0.0 & 0.0 & 19.0 \\
Electric Power Sector Development Program & 250.0 & 0.0 & 0.0 & 250.0 \\
First Road Infrastructure Program & 300.0 & 0.0 & 0.0 & 300.0 \\
Cantonal Road Network Program & 60.0 & 0.0 & 0.0 & 60.0 \\
& & & & \\
Nonreimbursable technical cooperation & $\mathbf{1 6 . 1}$ & $\mathbf{6 . 4}$ & $\mathbf{0 . 3}$ & $\mathbf{9 . 4}$ \\
Total & $\mathbf{9 0 3}$ & $\mathbf{7 6 . 1}$ & $\mathbf{1 0 . 6}$ & $\mathbf{8 1 6 . 2}$ \\
\hline
\end{tabular}

\section{Loan Disbursements}

(In millions of U.S. dollars)

\begin{tabular}{lcccrrrrrrr}
\hline & 2001 & 2002 & 2003 & 2004 & 2005 & 2006 & 2007 & 2008 & $2009^{1}$ \\
\hline $\begin{array}{l}\text { Disbursements } \\
\begin{array}{l}\text { Amortization } \\
\text { Interest and }\end{array}\end{array}$ & 31.5 & 45.1 & 88.4 & 100.2 & 41.6 & 22.5 & 13.0 & 18.0 & 84.6 \\
charges & 78.2 & 79.3 & 93.0 & 110.2 & 208.9 & 78.5 & 81.7 & $288.4^{2}$ & 50.1 \\
& 50.2 & 44.1 & 43.1 & 42.7 & 41.2 & 27.3 & 24.5 & 25.3 & 13.2 \\
Net cash flow & -96.9 & -78.3 & -47.7 & -52.7 & -208.5 & -83.3 & -93.2 & -295.7 & 21.3 \\
\hline
\end{tabular}

1/ Projections

2/ Includes an anticipated repayment of US $\$ 200$ million

\section{Lending Program for 2009 (tentative)}

\begin{tabular}{rr}
\hline Project & Amount (US\$ mill) \\
\hline Water and Sanitation Investment Program & 85.0 \\
\hline
\end{tabular}


IV. Statistical Issues

20. Economic and financial statistics are adequate for surveillance and program monitoring purposes. The quality of macroeconomic data has continued to improve in recent years. This was confirmed by a reassessment of the Data Module Report on the Observance of Standards and Codes (ROSC) that took place in April 2009. Further statistical improvements are being pursued, including in the real, monetary, fiscal, and balance of payments sectors. Costa Rica is in observance with the Special Data Dissemination Standards (SDDS). The Central Bank, the Ministry of Finance, and the National Institute of Statistics and Censuses make data available to the public through regular official publications on their websites (http://www.bccr.fi.cr and www.hacienda.go.cr) .

\section{Real sector}

21. A new consumer price index was introduced in August 2006 by the National Institute of Statistics and Censuses. It is based on an updated and expanded consumption basket, derived from a household survey conducted in 2004-05. The new and old CPIs were spliced, using July 2006 as the base period.

22. A new national account series was disseminated by the Central Bank in 2004.

The 1993 SNA was adopted as its conceptual framework and a wider database was generated, that allowed the expansion in the scope of the accounts. Consistent GDP estimates by production and expenditure approaches at current and constant prices, as well as by income approach at current prices, are generated in the framework of supply and use tables. However, the reference year 1991 for the series at constant prices is outdated, data available for the quarterly GDP estimates are limited in scope, and an excessive use is made of fixed coefficients that are more than five years old.

\section{Updates to the Producer Price Index (PPI) are not done on a regular basis} although it is expected that the index will be updated in 2010. The last update of the index was in 2000. There are few regular comprehensive industrial surveys that can be used to update the weights, the product sample, and the establishment sample for the PPI. Plans are underway to resolve this problem. As a first step, a draft of a new business register is now available.

24. An area for improvement pertains to the wage and employment data, which are currently available on an annual basis only. The authorities are looking at ways to enhance the periodicity, timeliness, and overall quality of the data collected from this sector. 


\section{Government finance statistics}

25. The Fund has launched a regional Government Finance Statistics (GFS) Harmonization Project that will last 18-24 months. A STA mission visited Costa Rica in late-March for the opening-workshop of the project, with the aim of establishing the modalities of collaboration, the expected outcomes in terms of moving toward harmonized standards and the medium-term process, and the actual data dissemination to the public in the short term, including the appropriate metadata.

26. Independently, Costa Rica has made progress compiling public finance data according to the IMF's Government Finance Statistics Manual (GFSM 2001). A plan to migrate to GFSM 2001 was designed in 2004, and the authorities have developed an integrated financial system for the budget and public debt as the starting point. They are working to better integrate systems for accounting, budgeting, and debt management. Further work is underway to address remaining weaknesses, including on the consistency and availability of consolidated public sector data. These include discrepancies between above-the-line fiscal figures and the financing side, and the need to standardize fiscal information on an accrual basis. In addition, nonfinancial public sector data are published only on an annual basis. A higher frequency would be critical to improve transparency and monitoring of the overall public sector.

\section{Monetary statistics}

27. Monetary and financial statistics are broadly in line with the IMF's Monetary and Financial Statistics Manual (MFSM). After successive TA missions to assist in the implementation of the MFSM (2001, 2003, 2007, and 2008), several important improvements have been made to the classification, coverage, and timeliness of the money and banking statistics. In 2008, the country started reporting data to STA using the standardized report forms (SRFs) for the central bank and other depository corporations (ODCs). Coverage of the ODC sector is still not complete, because data exclude money market funds and off-shore banks, which accept deposits from residents. The chart of accounts used by ODCs does not permit a proper sectorization of claims on and liabilities to domestic sectors, although additional data are provided by the ODCs to the BCCR. Costa Rica is participating in the regional project for harmonization of monetary and financial statistics in Central America, Panama, and the Dominican Republic, for which the SRFs constitute the source data. There is in place a unified reporting system for monetary data, which automatically generates the analytical tables used by WHD from the data submitted to STA.

\section{Balance of payments statistics}

28. Substantial progress has been made in the estimation of quarterly balance of payments and international investment position (IIP) statistics. Costa Rica has published quarterly balance of payment data (BOP) since 1999 and IIP data since 1996. In 2005, Costa Rica initiated the compilation and dissemination of quarterly IIP data. In September 2003, Costa Rica initiated the dissemination of quarterly external debt position data with one quarter lag on the central bank's website with a hyperlink to the Fund's website. As a SDDS subscriber, Costa Rica reports external debt data to the 
Quarterly External Debt Statistics (QEDS) website, and disseminates, on a monthly basis, the Data Template on International Reserves and Foreign Currency Liquidity.

29. The April 2009 Data Module ROSC mission found that Costa Rica has room for improving the coverage of private sector transactions in external sector

statistics. Weaknesses in coverage are observed in areas such as services, compensation of employees, and financial transactions of the private sector. Transfer prices in some cases are not converted to market prices. On public external debt, the accrued interest principle is not followed, but due date is recorded. Costa Rica will be able to receive additional technical assistance on BOP and IIP statistics within the context of CAPTAC's Harmonization Project of External Sector Statistics in Central America, the Dominican Republic, and Panama, in which all these issues will be addressed. 
Table of Common Indicators Required for Surveillance

(As of August 31, 2009)

\begin{tabular}{|c|c|c|c|c|c|c|c|}
\hline & \multirow{2}{*}{$\begin{array}{c}\text { Date of latest } \\
\text { observation }\end{array}$} & \multirow{2}{*}{$\begin{array}{l}\text { Date } \\
\text { received }\end{array}$} & \multirow{2}{*}{$\begin{array}{c}\text { Frequency } \\
\text { of Data }^{6}\end{array}$} & \multirow{2}{*}{$\begin{array}{l}\text { Frequency of } \\
\text { Reporting }\end{array}$} & \multirow{2}{*}{$\begin{array}{l}\text { Frequency } \\
\text { of } \\
\text { Publication }\end{array}$} & \multicolumn{2}{|c|}{ Memo Items: } \\
\hline & & & & & & $\begin{array}{c}\text { Data Quality - } \\
\text { Methodological } \\
\text { soundness }^{7}\end{array}$ & $\begin{array}{c}\text { Data Quality - Accuracy } \\
\text { and reliability }\end{array}$ \\
\hline Exchange Rates & Aug 09 & Aug 09 & $\mathrm{D}$ & $\mathrm{D}$ & $\mathrm{D}$ & & \\
\hline $\begin{array}{l}\text { International Reserve Assets and Reserve Liabilities of the } \\
\text { Monetary Authorities } 1\end{array}$ & Jun 09 & Aug 09 & $\mathrm{D}$ & $\mathrm{D}$ & $\mathrm{D}$ & & \\
\hline Broad Money & Jun 09 & Aug 09 & $\mathrm{M}$ & $\mathrm{M}$ & $\mathrm{M}$ & & \\
\hline Central Bank Balance Sheet & Jul 09 & Aug 09 & M & M & M & & \\
\hline Consolidated Balance Sheet of the Banking System & Jun 09 & Aug 09 & M & M & M & & \\
\hline Interest Rates ${ }^{2}$ & Jun 09 & Aug 09 & $\mathrm{D}$ & $\mathrm{D}$ & $\mathrm{D}$ & & \\
\hline Consumer Price Index & Jul 09 & Aug 09 & M & M & M & $\mathrm{O}, \mathrm{O}, \mathrm{LO}, \mathrm{O}$ & $\mathrm{LO}, \mathrm{O}, \mathrm{O}, \mathrm{NA}$ \\
\hline $\begin{array}{l}\text { Revenue, Expenditure, Balance, and Composition of } \\
\text { Financing }{ }^{3} \text { - General Government }{ }^{4}\end{array}$ & Jun 08 & Aug 09 & M & M & M & & \\
\hline $\begin{array}{l}\text { Revenue, Expenditure, Balance, and Composition of } \\
\text { Financing }{ }^{3} \text { - Central Government }\end{array}$ & Jun 08 & Aug 09 & M & M & M & & \\
\hline $\begin{array}{l}\text { Stocks of Central Government and Central Government- } \\
\text { Guaranteed Debt }\end{array}$ & Jun 08 & Aug 09 & M & M & M & & \\
\hline External Current Account Balance & Mar 09 & Jun 09 & Q & Q & Q & $\mathrm{O}, \mathrm{O}, \mathrm{O}, \mathrm{LO}$ & $\mathrm{LO}, \mathrm{O}, \mathrm{LO}, \mathrm{LNO}$ \\
\hline Exports and Imports of Goods and Services & Mar 09 & Jun 09 & Q & $\mathrm{Q}$ & Q & & \\
\hline GDP/GNP & Mar 09 & Jun 09 & Q & $\mathrm{Q}$ & $\mathrm{Q}$ & $\mathrm{O}, \mathrm{O}, \mathrm{LO}, \mathrm{O}$ & LNO, LNO, LO, LNO \\
\hline Gross External Debt & Mar 09 & Jun 09 & $\mathrm{Q}$ & Q & Q & & \\
\hline International Investment Position & 2008 & Jun 09 & A & A & A & & \\
\hline
\end{tabular}

${ }^{1}$ Includes reserve assets pledged or otherwise encumbered as well as net derivative positions.

${ }^{2}$ Both market-based and officially-determined, including discounts rates, money market rates, rates on treasury bills, notes, and bonds.

${ }^{4}$ The general government consists of the central government (budgetary funds, extra budgetary funds, and social security funds) and state and local governments.

Including currency and maturity composition.

Daily (D), weekly (W), monhly (M), quarterly (Q); annually (A); irregular (I); and not available (NA)

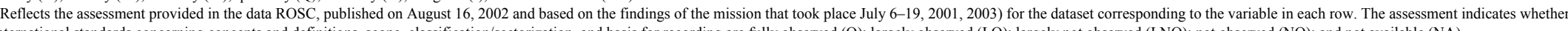

nd basis for recording are fully observed (O); largely observed (LO); largely not observed (LNO); not observed (NO); and not available (NA).

Same as footnote 7, except referring to international standards concerning source data, statistical techniques, assessment and validation of source data, assessment, and revision studies. 


\section{IMF Executive Board Approves First Review Under Costa Rica's Stand-By Arrangement}

The Executive Board of the International Monetary Fund today completed the first review of Costa Rica's economic performance under the 15-month, SDR 492.3 million (about US\$780 million) Stand-By Arrangement approved in April 13, 2009 (see Press Release No. 09/124). Completion of the review makes an additional SDR 41.025 million (about US\$65 million) available for disbursement, bringing the total resources available to Costa Rica under the arrangement to SDR369.2 million (about US\$585 million). The Costa Rican authorities intend to continue treating the arrangement as precautionary.

Following the Executive Board discussion on Costa Rica, Mr. Murilo Portugal, Deputy Managing Director and Acting Chair, made the following statement:

"The Costa Rican economy has withstood the impact of the global economic and financial crisis relatively well. The authorities' strategy to reduce the impact from external shocks through fiscal stimulus and the mobilization of contingent external financing, including the precautionary Stand-By Arrangement with the Fund, has helped sustain investor confidence and financial stability. Output, especially in sectors dependent on external conditions, has declined, but preliminary evidence suggests that the economy is bottoming out.

"The 15-month Stand-By Arrangement is expected to remain precautionary and will continue to support confidence through the availability of a substantial liquidity buffer. The program has been revised to partly accommodate lower-than-expected fiscal revenues through higher deficits in 2009-10. This will help protect social spending and support domestic demand, while keeping the domestic borrowing requirement and the debt-to-GDP ratio within reasonable margins. 
"Inflation has reached historical lows, providing the central bank with an opportunity to achieve durable price stability. Monetary policy will maintain its cautious, gradual easing bias conditional on a decline in inflation and exchange rate expectations.

"The banking sector remains sound. While the cyclical downturn of activity has led to a moderate increase in nonperforming loans and a decline in bank profitability, liquidity and solvency indicators remain generally adequate and banks have reduced their net foreign exposure by repaying external credit lines. The authorities will continue to monitor financial sector risks closely, and press ahead with their well-focused agenda to strengthen bank supervision, regulation, and the financial sector safety net.

"Overall, the near-term prospects for Costa Rica's economy have improved and external vulnerabilities have declined. The incipient global recovery should boost confidence, help lift export-related activities, and restore investor risk appetite. Some downside risks remain, especially if the global recovery falters or the fiscal borrowing requirement rises more than expected. Continued strong implementation of the policies under the IMF-supported program will help insulate Costa Rica's economic recovery from these downside risks." Mr. Portugal said. 


\section{INTERNATIONAL MONETARY FUND}

EXTERNAL

Public Information Notice (PIN) No. 09/124

FOR IMMEDIATE RELEASE

October 19, 2009
International Monetary Fund

$70019^{\text {th }}$ Street, NW

Washington, D. C. 20431 USA

\section{IMF Executive Board Concludes Article IV Consultation with Costa Rica}

On September 23, 2009, the Executive Board of the International Monetary Fund (IMF) concluded the 2009 Article IV consultation with Costa Rica. ${ }^{1}$

\section{Background}

The global crisis has hit Costa Rica hard. After experiencing an economic boom with output growth averaging 6.6 percent during 2003-2007, the Costa Rican economy decelerated sharply in 2008 as output growth turned negative in the fourth quarter of 2008 (-1.7 percent compared to the same quarter of the previous year) and continued to decline in the first quarter of 2009 (4.8 percent). A major correction in inventories and a decline in sectors most dependent on external conditions were key factors behind the slowdown. Nonetheless, the decline in output appears to be approaching an end. The index of economic activity rose 1.2 percent on a quarter-on-quarter basis in the second quarter of 2009, as output in key sectors stabilized. At the same time, inflation remained on a firm downward path, falling from 13.9 percent in December 2008 to 5.7 percent in August 2009, its lowest level in over 30 years.

Despite the worsening of economic activity, the banking sector has remained sound. Although the nonperforming loan ratio of banks has risen moderately and profitability declined in the first half of 2009, liquidity and solvency indicators remained adequate. With the slowdown in activity, demand for credit declined, contributing to a leveling of bank lending to the private sector.

\footnotetext{
${ }^{1}$ Under Article IV of the IMF's Articles of Agreement, the IMF holds bilateral discussions with members, usually every year. A staff team visits the country, collects economic and financial information, and discusses with officials the country's economic developments and policies. On return to headquarters, the staff prepares a report, which forms the basis for discussion by the Executive Board. At the conclusion of the discussion, the Managing Director, as Chairman of the Board, summarizes the views of Executive Directors, and this summary is transmitted to the country's authorities. An explanation of any qualifiers used in summings up can be found here: http://www.imf.org/external/np/sec/misc/qualifiers.htm.
} 
Nonetheless, bank deposits continued to grow, especially dollar-denominated deposits, allowing banks to repay foreign credit lines and reduce their net external position. In light of the strength of the balance of payments position, the authorities have treated the first purchase (about $\$ 500$ million) under the SBA as precautionary. ${ }^{2}$

Fiscal policy has provided significant support to domestic demand. The fiscal deficit of the central government increased to 1.3 percent of gross domestic product (GDP) in the first half of 2009 as noninterest expenditures rose 14 percent in real terms, despite a significant revenue shortfall. The central government's gross financing requirements, including large amortization payments were met through domestic bond issuances. Fiscal policy is expected to remain expansionary in the second half of 2009. As a result, the central government deficit for the year as a whole is expected to reach 4.1 percent of GDP, compared to a deficit of 0.3 percent of GDP in 2008.

Monetary conditions have tightened somewhat in 2009. Despite the rapid decline in inflation, nominal rates of colon-denominated deposits and government bonds remained largely unchanged, contributing to an increase in real interest rates. In July 2009, the central bank lowered its key policy interest rate by 100 basis points to 9 percent in July 2009. The exchange rate has remained close to the ceiling (most depreciated end) of the currency band so far in 2009, though occasionally traded up to 2 percent below the ceiling. Central bank (BCCR) interventions were generally moderate.

Near term prospects have improved. Although real GDP is estimated to decline by 1.5 percent in 2009 , it is projected to increase by 2.3 percent in 2010 as activity recovers. Inflation would continue to drop to reach 5 percent by end-2009, pulled down by economic slack, prudent monetary policy, and the lagged effect of the commodity price adjustment. After a sharp contraction in 2009 to 3.6 percent of GDP, the current account deficit is expected to widen in 2010 to 4.8 percent of GDP, as imports bounce back with the economic recovery. Nonetheless, some downside risks to this outlook remain. Concerns about the sustainability of the incipient global recovery could weigh in on domestic demand and a concomitant loss in domestic confidence could weaken the balance of payments.

\section{Executive Board Assessment}

Executive Directors noted that the Costa Rican economy has withstood the impact of the global crisis relatively well. Directors commended the authorities for their strong policy performance focused on preserving stability, protecting the external position, and supporting the nascent recovery. They welcomed the prospects for positive output growth in 2010 and a gradual return to potential growth over the medium term.

While noting that the immediate risks to Costa Rica's economic outlook have moderated with the stabilization of the global financial environment, Directors encouraged the authorities to

\footnotetext{
${ }^{2}$ The 15-month Stand-By Arrangement (SBA) with total access of SDR 492.3 million (about US\$740 million) was approved in April 2009.
} 
remain vigilant as confidence could weaken if the incipient recovery falters or the fiscal deficit widens more than expected. They emphasized that timely implementation of structural reforms in the areas of fiscal revenues and the financial sector will be key to maintain the positive growth momentum.

Directors noted that fiscal policy should continue to strike a balance between supporting domestic demand and keeping domestic government borrowing and the public debt in check. Once the recovery takes hold, the fiscal deficit should be brought down to reduce the debt burden and rebuild fiscal space. Achieving this goal, while maintaining higher levels of public investment and social spending, will require a substantial increase in revenues, including by broadening the tax base and strengthening tax administration.

Directors welcomed the recent decline in inflation, which would strengthen monetary policy credibility and facilitate the transition to inflation targeting. Directors encouraged the authorities to move forward with the recapitalization of the central bank, and recommended further steps to improve communications and the coherence of the monetary policy framework, including by clarifying the central bank's role in the debt and foreign exchange markets.

Directors observed that Costa Rica's balance of payments has adjusted rapidly to the deterioration in the external environment. They noted staff's findings that the current level of the real effective exchange rate remains broadly in line with fundamentals. Most Directors found merit in a gradual build up of international reserves over the medium term to further improve resilience to external shocks.

Directors agreed that the banking sector remains sound. While the cyclical downturn of activity has led to a moderate increase in nonperforming loans and a decline in bank profitability, liquidity and solvency indicators remain adequate and banks have reduced their net foreign exposure by repaying external credit lines. Directors welcomed the planned implementation of risk-based supervision and called for strengthened market discipline by modifying legal provisions that limit the dissemination of prudential indicators for individual banks. They encouraged the authorities to continue to monitor financial sector risks closely, and to press ahead with their well-focused reform agenda to strengthen bank supervision, regulation, and the financial sector safety net.

It is expected that the next Article IV consultation with Costa Rica will be held in accordance with the Executive Board decision on the consultation cycle for members with Fund arrangements.

Public Information Notices (PINs) form part of the IMF's efforts to promote transparency of the IMF's views and analysis of economic developments and policies. With the consent of the country (or countries) concerned, PINs are issued after Executive Board discussions of Article IV consultations with member countries, of its surveillance of developments at the regional level, of post-program monitoring, and of ex post assessments of member countries with longer-term program engagements. PINs are also issued after Executive Board discussions of general policy matters, unless otherwise decided by the Executive Board in a particular case. The staff report (use the free Adobe Acrobat Reader to view this pdf file) for the 2009 Article IV Consultation with Costa Rica is also available. 
Costa Rica: Selected Economic Indicators

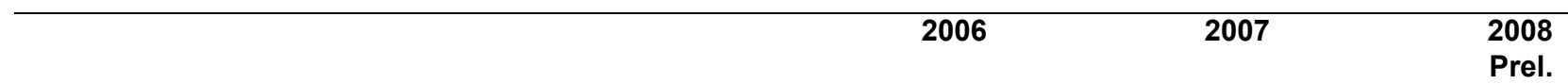

(Annual percentage change, unless otherwise indicated)

National Income and Prices

GDP at constant prices

Implicit deflator

Consumer prices (end of period)

External Sector

Exports of goods (volume, FOB)

Imports of goods (volume, CIF)

Terms of trade (deterioration -)

Real Effective Exchange Rate (eop; depreciation -)

\section{Money and Credit}

Base money

Broad money

Bank credit to private sector

Lending interest rate (end of period)

\section{Public Finances}

Combined public sector primary balance 1/

Combined public sector overall balance 1/

Combined public sector debt (gross) 1/

Of which: External public debt

\section{Savings and Investment}

Gross domestic investment

Gross national savings

\section{External Sector}

Trade balance

Current account balance

Foreign direct investment

\section{Memorandum items}

Change in net international reserves (increase -)

Net international reserves 2/

Gross Domestic Product

8.8

11.0

9.4

10.6

9.3

$-3.9$

0.9

26.9

25.3

28.5

20.7

(In percent of GDP)

\section{8}

$-0.7$

47.8

13.1

26.4

21.3

$-12.7$

$-5.1$

6.1
7.8

9.3

10.8

9.2

4.1

$-3.7$

2.8

33.0

16.3

38.3

16.3
11.9

17.3

31.8

20.7

2.6

12.1

13.9

$-3.4$

5.8

$-4.6$

5.4

11.9

8

7




\section{Statement by Ramon Guzmán, Executive Director for Costa Rica and Johnny Gramajo-Marroquin, Senior Advisor}

September 23, 2009

We would like to thank Staff for a comprehensive and well-written set of papers. Our Costa Rican authorities broadly agree with the Staff's assessment. Performance under the Program was very strong; all quantitative performance criteria for end-June were meet, most with significant margins. Costa Rica has also complied with all three end-June structural benchmarks. The authorities intend to continue treating the arrangement as precautionary.

After five years of robust growth, averaging 6.6 percent per year, the Costa Rican economy has experienced a considerable slowdown since last quarter of 2008 as the United States, its main trade partner, and the rest of the world entered the current recession. In that context, the global crisis has hit Costa Rica hard, but the economy continues to withstand the negative shock reasonably well. Active policies have helped preserve stability and mitigate the negative impact on domestic demand. During the first quarter of 2009 real GDP contracted 4.8 percent $(\mathrm{y} / \mathrm{y})$ being substantially weaker than envisaged, however, short-term economic activity indicators have shown some evidence that the real GDP decline is reaching an end.

At the same time, inflation has declined faster than expected, to a 30-year low of 5.7 percent in August. Authorities agree with Staff that advancing in the transition to an inflationtargeting regime - supported by increased exchange rate flexibility — could be useful to achieve price stability, helping anchor inflation expectations around the Central Bank's inflation target.

On the fiscal side, government revenues for 2009 are expected to fall short of the original projection by around 1.7 percent of GDP. This shortfall is the result mainly of a larger than anticipated decline in import-related taxes. About one half of the lower revenue will be accommodated through a higher deficit to protect the planned increase in government noninterest spending. Overall, the revised program now envisages a central government deficit of 4.1 percent of GDP and a deficit of the combined public sector of 4.8 percent of GDP. The increase in the deficit over previously programmed shall be financed by domestic borrowing and, if necessary, by the use of central government deposits. In the case of 2010, the program anticipates a deficit for the central government of 4.1 percent of GDP and a combined public sector deficit of $4.7 \%$ of GDP.

It is important to underline that although mentioned deficits are higher than the original, they continue to imply a small adjustment in structural terms. In this regard, my authorities also want to highlight to the Board that planned spending was central to their objective of fostering investment in human and physical capital. They feel that risks of deficit expansion 
to stability are manageable, and want to stress their commitment to begin the fiscal consolidation process as soon as the economic recovery takes hold.

The external current account deficit has narrowed substantially, and the overall balance of payments was in surplus during the first half of 2009. For end-2009, the current account deficit is expected to decline to 3.6 percent of GDP (5.3 percent of GDP at program approval) and thereafter to increase to 4.8 percent of GDP in 2010. The balance of payments is projected to remain in overall balance in 2009. In addition, our Costa Rican authorities share the Staff's assessment that the level of real effective exchange rate is broadly in line with fundamentals.

The banking system has remained sound, despite some hike in nonperforming loans and a decline in bank profitability. Although concerns about risks to bank liquidity have eased, the Superintendency of Banks will continue to closely monitor developments in the banking sector, particularly credit risks. The authorities are working on draft laws to strengthen the bank resolution framework and create a limited deposit guarantee scheme, which are scheduled to be submitted to the Legislative Assembly by end-December 2009.

The medium-term outlook for Costa Rica's economy remains generally favorable. However, authorities are aware that the following actions are desirable: i) after a large fiscal expansion, it will be necessary to reduce the fiscal deficit to keep the debt burden in comfortable levels; ii) advancing in implementation of inflation targeting regime and providing greater exchange rate flexibility can help to achieve price stability; and iii) to continue enhancing the supervision and prudential framework, and safety net for banks.

Authorities believe that the ongoing policies are adequate to meet the objectives of their program. However, if needed, the government stands ready to take additional measures. 